\title{
Carboniferous auloporids from the Iberian Peninsula: palaeocology, diversity, and spatio-temporal distribution
}

\author{
I. Coronado ${ }^{1,2 *}, \mathrm{~S}$. Rodríguez ${ }^{1,2}$ \\ ${ }^{1}$ Departamento de Paleontología, Facultad de Ciencias Geológicas, Universidad Complutense de Madrid, E-28040 Madrid, Spain \\ ${ }^{2}$ Instituto de Geociencias IGEO (CSIC, UCM). C/ José Antonio Nováis 2, Ciudad Universitaria. E-28040 Madrid, Spain \\ e-mail addresses: ismael.coronado@geo.ucm.es (I.C., *corresponding autor); sergrodr@geo.ucm.es (S.R.)
}

Received: 23 July 2012 / Accepted: 4 December 2013 / Available online: 25 February 2014

\begin{abstract}
Auloporid corals are common in the Palaeozoic and very frequent in the Carboniferous buildups of the Iberian Peninsula. The aim of this study is to analyze the diversity of these corals through a taxonomical recognition of the species and morphotypes that occur in the Iberian Peninsula. Eighteen sections have been sampled between the Ossa-Morena (Mississippian) and Cantabrian (Pennsylvanian) zones dated as upper Viséan to early Kasimovian. In addition, other localities where auloporids occur and are cited in the literature have been also used for this study. The taxonomical identification has been carried out using the criteria proposed by Tchudinova (1980) with little modifications. Thus, eighteen morphotypes and two species belonging to nine nominal genera have been identified (Multithecopora sp. A-H, Syringopora sp. A-B, Aulopora sp. A-B, Cladochonus sp. A-B, Syringoalcyon sp., Roemeripora sp., Sinopora sp., Mastopora? sp., Multithecopora hontoriense and Neomultithecopora cantabrica). Through a classical microfacies study, the environments where the auloporids lived have been identified, as well as the growth patterns and the features of sedimentation. Finally, a preliminary biostratigraphic range chart for the Carboniferous auloporoids from the Iberian Peninsula has been achieved.
\end{abstract}

Keywords: Iberia, Ossa-Morena Zone, Cantabrian Zone, Auloporid corals, Carboniferous

Resumen

Los corales aulopóridos son muy comunes en el Paleozoico y muy frecuentes en las bioconstrucciones del Carbonífero de la Península Ibérica. Con el objetivo de analizar la diversidad de estos corales, se ha llevado a cabo un detallado estudio de los morfotipos y especies de aulopóriodos carboníferos que aparecen en la Península Ibérica. Para ello se han estudiado 18 secciones repartidas entre la Zona de Ossa-Morena (Missisípico, ) y la Zona Cantábrica (Pennsylvánico), con edades comprendidas entre el Viseense superior y el Kasimoviense inferior. Así mismo para este estudio se han tenido en cuenta otros aulóporidos ya identificados en trabajos previos. La identificación taxonómica se ha realizado siguiendo los criterios propuestos por Tchudinova (1980) con algunas modificaciones. De esta manera se han identificado dieciocho morfotipos y dos especies que pertenecen a nueve géneros (Multithecopora sp A-H, Syringopora sp A-B, Aulopora sp A-B, Cladochonus sp A-B, Syringoalcyon sp, Roemeripora sp, Sinopora sp, Mastopora? sp, Multithecopora hontoriense and Neomultithecopora cantabrica). Mediante un estudio clásico de las microfacies asociadas a los aulopóridos de la Península Ibérica se han identificado los ambientes y características de crecimiento o depósito. Por último se ha realizado una tabla bioestratigráfica preliminar con los datos de los que se dispone actualmente.

Palabras clave: Iberia, Zona de Ossa-Morena, Zona Cantábrica, Corales aulopóridos, Carbonífero

\section{Introduction and background}

\subsection{Introduction}

Auloporida Sokolov, 1947 is an order of tabulate corals that are very abundant during the Palaeozoic Era. Their dis- tribution ranges from Early Ordovician to Late Permian (Hill, 1981). Auloporids are both primary and secondary builders in the Carboniferous and had an important role along with the algae and others corals in the development of reef limestones (Said et al., 2010; Poty, 2010; Aretz and Herbig, 2010). Wahlman (2002) stated that auloporoids are closely related 
to chaetetids in his chaetetid-buildups and Minwegen (2001) described the same relationship in the buildups of the Cantabrian Zone, referring to this association as 'chaetetid-coral reef mounds' (Korallen-Chaetetiden-Reefmounds).

Although this group is common in the record, there are few palaeontological studies on Carboniferous auloporids in the Iberian Peninsula. In a general way, this group has been frequently cited, but not described, in palaeontological and geological studies of the Carboniferous of the Iberian Peninsula as auloporid, syringoporid or tabulate corals.

This article represents a compendium of the variety and diversity of Carboniferous auloporid taxa found in the Iberian Peninsula, and the different type of facies and environments in which they grew. The stratigraphic distributions as well as the growth-patterns used by auloporid corals are also objectives of this paper. An exhaustive sampling and identification of the auloporid corals of the Iberian Peninsula in eighteen sections was made to achieve this goal. These sections are spread through the Ossa-Morena (Mississippian) and Cantabrian (Pennsylvanian) zones (Fig. 1) dated as late Viséan to early Kasimovian. Additionally, other information obtained from the literature is also included in this work. The criteria used for the identification and characterization of the genera were those proposed by Tchudinova (1980) and are analysed below.

\subsection{Background}

Auloporids have been cited in Mississippian (Ossa-Morena Zone) materials: Cózar et al. (2007), and Cózar and Rodríguez (1999) cited the presence of tabulate corals in reference to Auloporida in Peñarroya-2 section, Córdoba (Spain). Cózar and Rodríguez (2000), Cózar and Rodríguez (2001) and Rodríguez and Rodríguez-Curt (2002) cited the occurrence of tabulate corals in reference to Auloporida in Antolín-1 section, Antolín- 3 section and Sierra Boyera section, Córdoba (Spain). Cózar et al. (2007) described the Fuenteobejuna section and found abundant tabulate corals which correspond with Auloporida in Córdoba (Spain). Rodríguez et al. (1992) and Rodríguez (1996) identified Syringopora, Pleurosyphonella and other tabulate corals in the Cerro de los Santos, Cerro Almeña and El Torreón sections from the Carboniferous Basin of Los Santos de Maimona, Badajoz (Spain).

Cózar and Rodríguez (2001) found tabulate corals in the Camino del Águila section, which correspond with remains of Auloporida. Gómez-Herguedas and Rodríguez (2008) found tabulate corals that were identify as syringoporids and/ or auloporids in the La Cornuda section, Córdoba (Spain).

Within the Betic Cordillera, auloporid corals were cited by Herbig (1984) in the Marbella Conglomerates, which are a subunit of the Malaguide Complex, Málaga (Spain). The auloporids occur within post-Viséan carbonate pebbles.

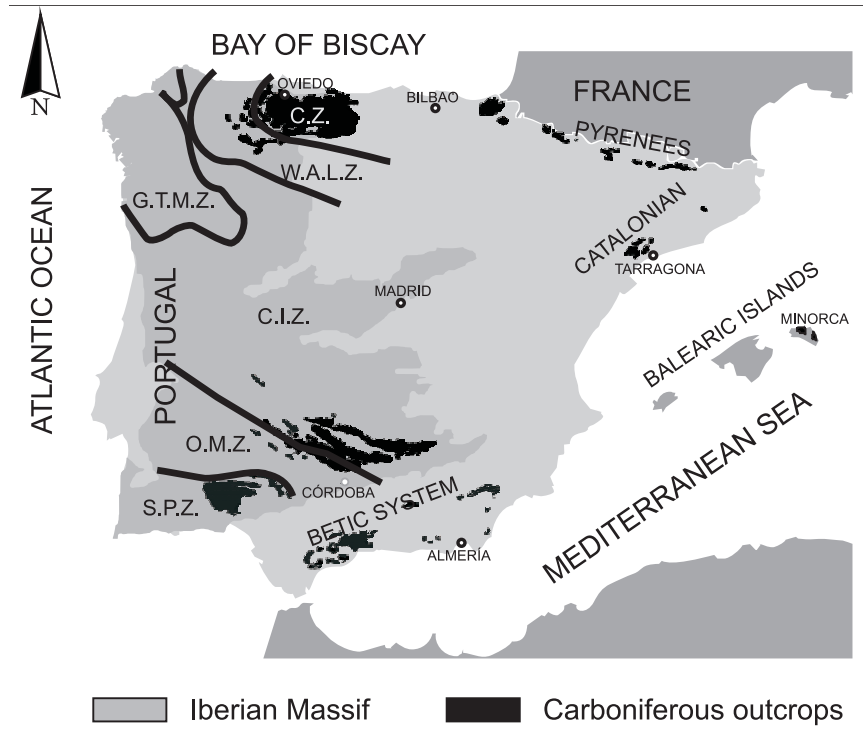

Fig.-1.- Synthetic map showing the distribution of the main Carboniferous outcrops of the Iberian Peninsula. (Cantabrian Zone, C.Z.; West- Asturian-Leonese Zone, W.A.L.Z.; Galicia-Tras os Montes, G.T.M.Z.; Central-Iberian Zone, C.I.Z.; Ossa-Morena Zone, O. M. $Z$. and South Portuguese Zone, S.P.Z.) Modified from Colmenero et al. (2002).

Numerous outcrops yielded auloporoids in the Pennsylvanian (Cantabrian-Zone).Winkler Prins (1971) described the type section of the Valdeteja Formation, in the Barcaliente Valley, León (Spain) and found some tabulate corals, citing Cladochonus sp. and Paleofavosites sp. Later Eichmüller (1985) described additional sections of the Valdeteja Formation and found numerous samples of a syringoporid coral that was classified as Sinopora. Recently, Villa et al. (2001) analyzed the biostratigraphic sequence of this section and described some facies containing auloporid corals.

van de Graaff (1971a) cited small colonies of auloporid corals in growth-position related to chaetetids in the Piedrasluengas Limestone, Palencia (Spain).

van Loon (1971) mentioned syringoporoid corals together with other fossil remains in the Pando Limestone section, at the Pando Pass and in the road to Prioro, León (Spain). Later, Fernández and Barba (1992) identified auloporoid corals in the Pando Pass.

The only taxonomical study on auloporids in the Spanish record was presented by Rodríguez and Ramírez (1987). These authors described the taxonomical characteristics of two genera and three new species of auloporids that occur in the La Playa de la Huelga section, Asturias (Spain) and interpreted the environments of growth. Later, this section was studied by Minwegen (2001), who identified the same genera. Similarly, the transect of San Antolín-La Huelga was described by Bahamonde et al. (2008), who also recognized syringoporid corals.

Minwegen (2001) studied the microfabrics and building organisms dominant during the Carboniferous in several sec- 
tions of the Cantabrian Zone as indicated above. This author recognized auloporid corals associated with chaetetids in the Villanueva section, Asturias (Spain). Likewise she recognized syringoporoids in the Piedrasluengas limestone as well as $\mathrm{Ne}$ omultithecopora in the Fuente De section, Cantabria (Spain).

The Fuente De section (sensu Minwegen, 2001) was also studied by Martínez-Chacón et al. (2001) and Merino-Tomé et al. (2009), who identified the genus Neomultithecopora, forming small buildups associated with chaetetids, in Cantabria (Spain).

Rodríguez et al. (1997) identified some taxa of rugose corals in a section near Ribadesella town, Asturias (Spain), where numerous incrustations of auloporid corals occur on the rugose coral skeletons.

Coronado and Rodríguez (2009) recognized syringoporoid corals in the algal-mounds of Cosgaya Formation in Cantabria (Spain) where they occur associated with calcareous algae, chaetetids and rugose corals.

Corrochano et al., (in press) found syringoporid corals in the Lena Group within the Levinco Formation, León (Spain) and Corrochano et al. (2009) identified syringoporid corals in the Bachende Limestone in León (Spain) also included in the Lena Group.

\section{Geological settings}

The outcrops sampled belong to the Carboniferous rocks of the Iberian Peninsula (Fig. 1). These materials crop out mainly in the Iberian Massif (Lotze, 1945; Julivert, 1971), which occupies almost half of the Iberian Peninsula and corresponds with the European zone of the Variscan Belt. There are additionally a number of smaller Carboniferous outcrops, separated by a Mesozoic and Cenozoic cover, exposed in the Iberian Range, Pyrenees, Catalonian Coastal Ranges, Minorca and Betic Cordillera (Colmenero et al., 2002). See figures 2 and 3 for the location of the eighteen studied and sampled sections in the Ossa-Morena and Cantabrian Zones of the Iberian Massif.

\subsection{Ossa-Morena Zone}

The Ossa-Morena Zone is located in the southwestern part of the Iberian Massif, and contains two marine Mississippian basins: the Guadiato Area and the Los Santos de Maimona Coal Basin (Wagner, 2004). Nine sections have been sampled in both basins.

The Guadiato Area is situated in Córdoba province and is a large and complex area in SW Spain (Fig. 2) that comprises Mississippian siliciclastic and limestone rocks. It is divided into three bands (Cózar and Rodríguez, 1999): 1) Fresnedoso Unit, composed mainly of Viséan siliciclastic rocks, 2) San Antonio-La Juliana Unit, composed of Serpukhovian siliciclastic and limestone rocks, and 3) Sierra del Castillo Unit, composed mainly of Viséan limestone rocks. Most palaeontological and stratigraphical studies were focused on the Viséan units. This is especially marked for studies on rugose corals, (Rodríguez 1985; Rodríguez and Falces, 1996; Rodríguez et al., 2001; Rodríguez and Somerville, 2007; Gómez-Herguedas and Rodríguez, 2008).

Seven sections have been sampled in the Guadiato Area (Córdoba province): La Adelfilla, Sierra de la Estrella, El Collado, Antolín, Fuenteobejuna, San Antonio and La Cornuda (Fig. 2).

Only two sections (Los Santos de Maimona and Cerro Almeña) have been sampled in Los Santos de Maimona Coal Basin that is located in the Badajoz province, between the towns of Los Santos de Maimona, Fuente del Maestre, and Feria. The Carboniferous outcrops form a narrow strip $11 \mathrm{~km} \mathrm{SE-}$ NW and a width of 1 to $3 \mathrm{~km}$, NE-SW (Fig. 2) and is formed by siliciclastic and carbonate materials, and small volcanic bodies, with a Mississippian age (Rodríguez et al., 1992).

\subsection{Cantabrian Zone}

The Cantabrian Zone is the most northern part of the Iberian Massif (Lotze, 1945), located in the north-west of the Iberian Peninsula. In this area, five zones can be distinguished from a structural point of view, with boundaries set by major thrusts. These are, from west to east: Fold-and-Thrust region (Somiedo-Correcillas, Sobia-Bodón and Aramo units), Central Carboniferous Coal Basin, Thrust Region (Ponga Unit), Picos de Europa Unit, and Pisuerga-Carrión Unit (Fig. 3). Overall, they show a vergence towards the east or the north, with the western units overthrusting the eastern ones. The Pisuerga-Carrión Region or Unit, in the innermost part, is overthrusted by all the surrounding units.

Nine sections have been sampled in different units of the Cantabrian Zone (Fig. 3): Manto del Esla (Prioro section, León province); Manto del Ponga (Ribadesella and Playa de la Huelga sections, Asturias province); Sobia-Bodón (Valdeteja section and Las Majadas section, León province); Pisuerga-Carrión (Las Ilces section in Cantabria province, Piedrasluengas, Este de Camasobres, Celada de Roblecedo Sur and Pico Guillermo sections in Palencia province).

\section{Material of study and methods}

Eighteen sections have been sampled searching for auloporid corals. The sampling consisted in the collection of complete colonies, fragments of colonies or fragments of corallites in facies associated with buildups in all of the sections, except in Ribadesella. Ten solitary rugose corals were sampled in this section, because auloporid corals only occur encrusting the rugosans.

520 thin-sections of auloporid corals have been prepared to study the inner characters. The specimens from Ribadesella were partly covered with marls and clays. For this reason, ten corals were cleaned with an $8 \%$ sodium hexametaphosphate solution during 18 hours to remove the sediment. Later, three thin-sections were made, two of them to observe the inner 


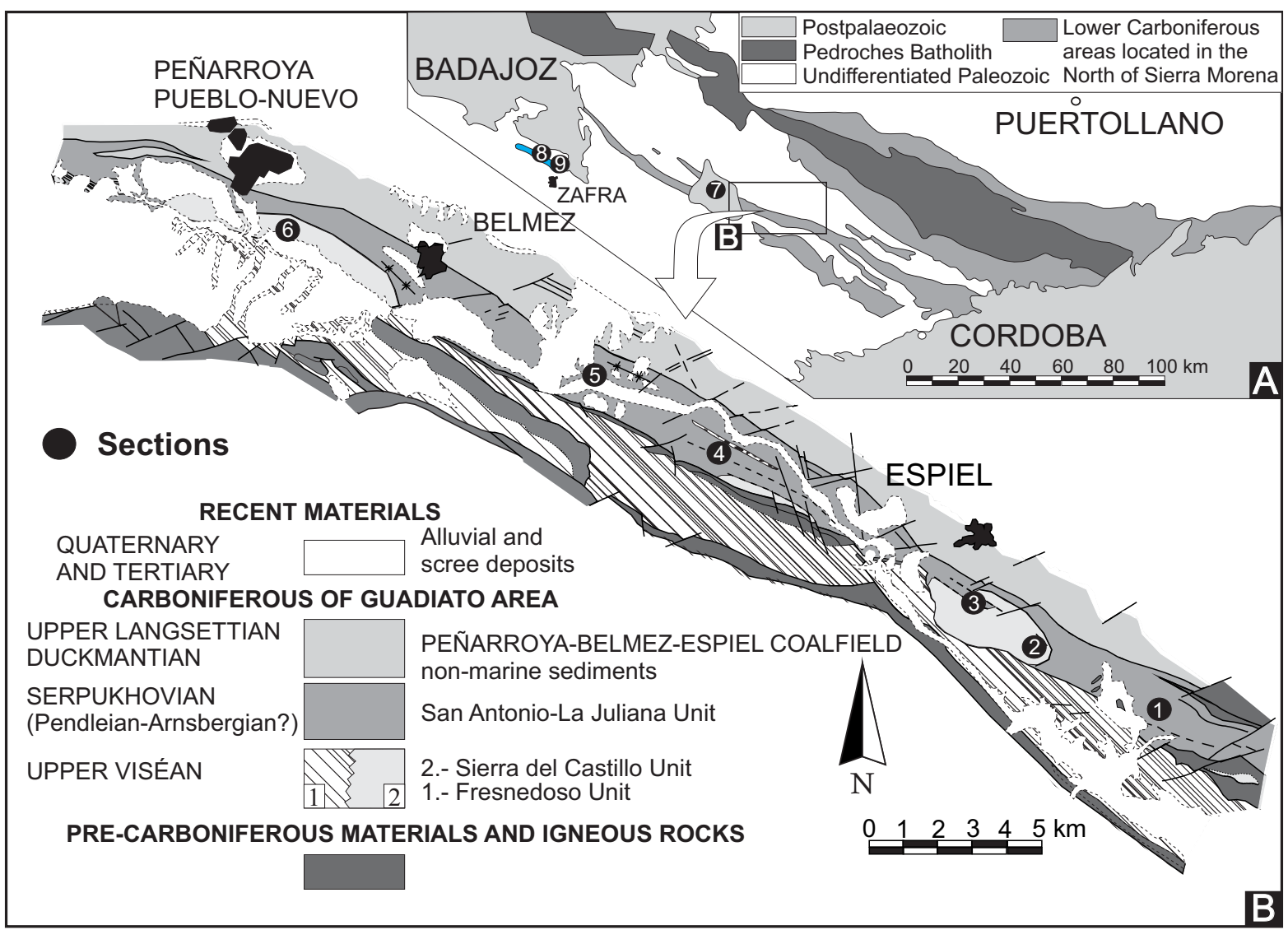

Fig.-2.- A) Early Carboniferous outcrops (upper Tournaisian to Arnsbergian) in the northern Sierra Morena. B) Synthetic map of the main geological units of the Guadiato Area. Location of the sampled sections. 1) La Adelfilla; 2) Sierra de la Estrella; 3) El Collado; 4) La Cornuda; 5) San Antonio; 6) Antolín; 7) Fuenteobejuna 8) Cerro Almeña; 9) Los Santos de Maimona. Modified from Cózar and Rodríguez (1999).

characters. In addition, some colonies have been cut and polished to observe the growth stages of the colonies.

Likewise, additional occurrences of auloporids have been identified with references in the literature (Minwegen, 2001; Merino Tomé et al., 2009).

\section{Descriptions}

\subsection{Localities}

The sections mentioned in this chapter have been described in detail in previous papers. Consequently, we will not describe them in detail, but will provide short reports on their most representative lithologies and palaeontological content. Temporal distributions of sections are displayed in Fig. 4.

\section{Ossa-Morena Zone:}

La Adelfilla, Fuenteobejuna and San Antonio. (San Antonio-La Juliana Unit). Described and figured by Cózar et al. (2007) and Cózar and Rodríguez (2004).These localities correspond to Viséan olistoliths in Serpukhovian olistostromes. La Adelfilla shows several imbricated olistoliths. Its thickness is about $40 \mathrm{~m}$ thick. It consists of bioclastic massive limestones, brecciated limestones and oolitic limestones. The sec- tion has been dated from the microfauna as late Viséan (Brigantian). The Fuenteobejuna section is $140 \mathrm{~m}$ thick, mostly composed of limestones, shales and polymictic breccias in the upper part. The section has been dated from microfauna and the microflora as late Viséan (late Asbian to early Brigantian). San Antonio section consists of limestones interbedded with shales and marls. The limestones are wackestones and grainstones. The section has been dated from the foraminiferal assemblage as early Serpukhovian (Pendelian). The facies that yielded corals are bioclastic limestones that are irregularly distributed in the olistoliths. They are coarse grained and corals are related to a diverse assemblage of invertebrates and algae. The original environment for those sections was open marine, shallow, agitated water (Cózar and Rodríguez, 1999).

Sierra de la Estrella. (Sierra del Castillo Unit). Described and figured by Cózar et al. (2003). It consists of a $234 \mathrm{~m}$ thick succession of bioclastic and massive limestones with interbedded marls. The auloporids from Sierra de la Estrella occur in well-bedded biostromal limestones at the top of microbial mounds. They represent the capping beds of the mounds, when they reached shallow waters. The section has been dated from foraminiferal assemblage as Zone 15 of Mamet, 1974 (middle part of the late Viséan, Asbian).

El Collado. (Sierra del Castillo Unit). Described and figured by Cózar (2004). This section comprises more than 150 


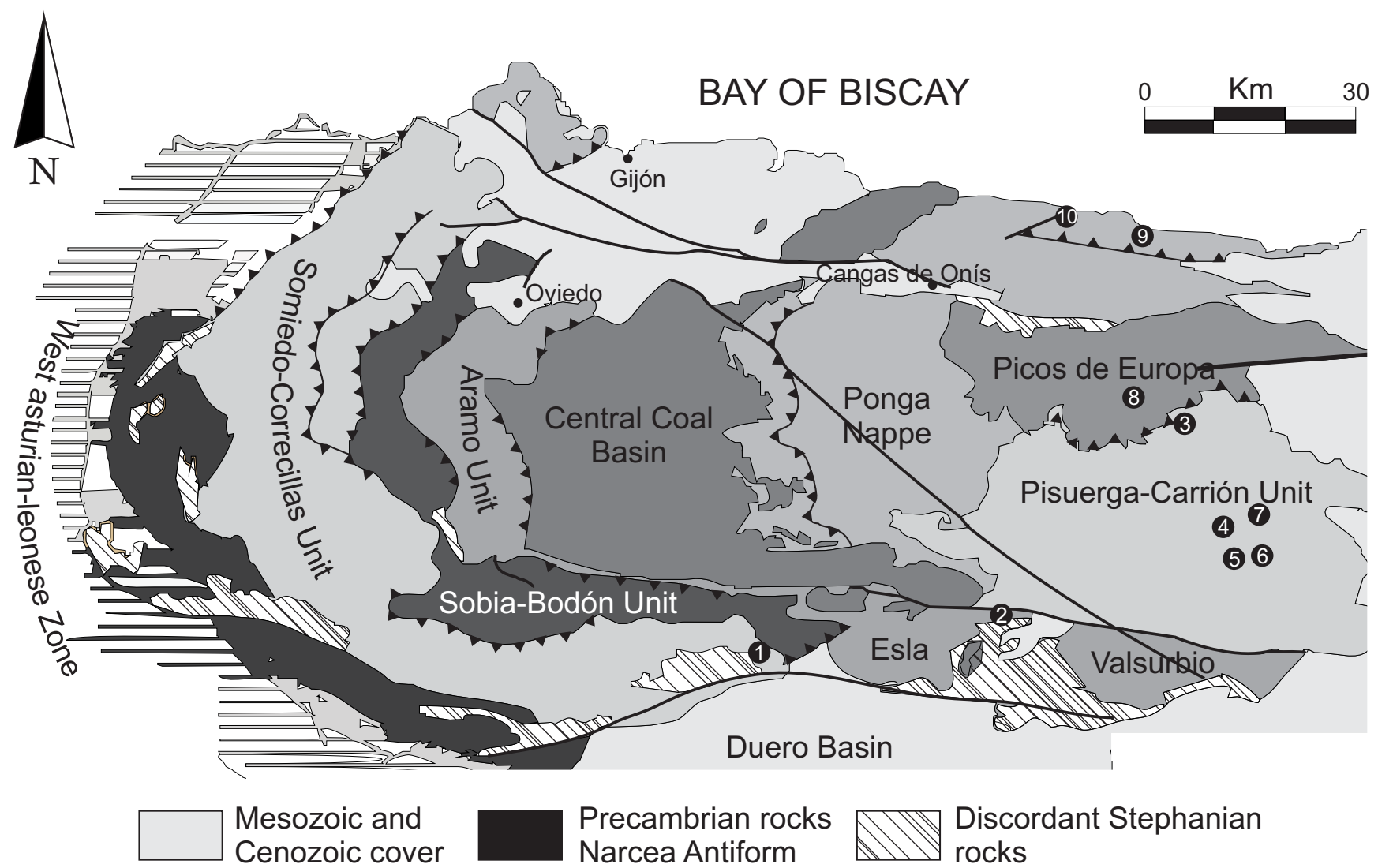

Fig. 3.- Synthetic map of the main geological units of the Cantabrian Zone. Location of the sampled sections. 1) Valdeteja; 2) Prioro; 3) Las Ilces; 4) Piedrasluengas; 5) Este de Camasobres; 6) Celada de Roblecedo; 7) Pico Guillermo; 8) Morra de Lechugales; 9) Playa de la Huelga; 10) Ribadesella. Modified from Pérez-Estaún et al. (2004).

metres of cyclic sedimentation of limestones and marls, in a shallow-water platform. The section has been dated from the foraminiferal assemblage as late Viséan (Asbian-Brigantian). The beds containing auloporids correspond to storm beds that reworked a rich assemblage dominated by colonial rugose corals.

Antolín. (Sierra del Castillo Unit). Described and figured by Cózar and Rodríguez (2000).This section comprises limestone debris $15 \mathrm{~m}$ thick in a mainly siliciclastic rhythmic sedimentation. It is typical from proximal turbidites. This section has been dated as late Viséan (Asbian-Brigantian). The reworked limestones originated in patch reefs located in the border of the talus (Rodríguez and Rodríguez-Curt, 2002).

La Cornuda. (San Antonio-La Juliana Unit). Described and figured by Gómez-Herguedas and Rodríguez (2008). This section is the only Serpukhovian autochthonous outcrop that yielded auloporids in Sierra Morena. It consists of limestones, calcareous sandstones and conglomerates $500 \mathrm{~m}$ thick. The section has been dated from foraminiferal assemblage as early Serpukhovian zones 17 and 18 (Pendleian). Auloporids encrusted rugose corals in shallow-water, coral-algal-microbial mounds (Gómez-Herguedas and Rodríguez, 2008).

Los Santos de Maimona. (Los Santos de Maimona Coal Basin). Described and figured by Rodríguez et al. (1992). Consist of $35 \mathrm{~m}$ of marls, limestones and marly limestones.
The section has been dated as late Viséan, zone 15 (Asbian). Auloporoids in Los Santos occur in well-bedded biostromal limestones that have been regarded as a reef-flat (Rodríguez, 1996). They are one of the main building organisms together with gigantoproductid brachiopods and rugose corals.

Cerro Almeña. (Los Santos de Maimona Coal Basin). Described and figured by Rodríguez et al. (1992). It consists of $90 \mathrm{~m}$ of alternating limestones, marly limestones and shales. This section has been dated as late Viséan, Zone 15 and 16 (Asbian-Brigantian subtage). Well-bedded to massive bioclastic limestones contain common reworked fragments of auloporoids and some entire colonies at the top of the beds. They lived in calcareous shoals and are accompanied by a diverse assemblage containing different invertebrates, foraminifers and algae.

\section{Cantabrian Zone:}

Valdeteja and Las Majadas (Valdeteja Formation, SobiaBodón Unit). Calcareous succession up to $700 \mathrm{~m}$ thick cropping out in the Somiedo-Correcillas, Sobia-Bodón, northern part of the Central Asturian Coalfield, Ponga Nappe, and Picos de Europa structural units of the Cantabrian Zone. The Valdeteja Formation was first described by Winkler Prins (1971), who identified the auloporid genus Cladochonus. 
Eichmüller (1985) described different sections and outcrops of Valdeteja Formation and identified mounds built by calcareous algae and reef mounds containing the auloporoid coral Sinopora sp.

The Valdeteja Formation has been dated as early Bashkirian-early Moscovian (Villa et al., 2001).

Las Ilces (Cosgaya Formation, Pisuerga-Carrión Unit). Described and figured by Coronado and Rodríguez (2009). It consists of a calcareous section $35 \mathrm{~m}$ thick, composed of limestones, which occasionally alternate black shales and marls. The Cosgaya Formation is composed of bioclastic limestones that show abundant algae and corals and locally form mounds (bioherms?). Those mounds are conspicuous at Las Ilces Section. Auloporoids are common in the mounds and in the surrounding facies. The age of the sections was established by fusulinids as late Bashkirian (Coronado, 2008).

Piedrasluengas (Piedrasluengas Formation, Pisuerga-Carrión Unit). This section comprises $300 \mathrm{~m}$ of limestones and marls. The Piedrasluengas Limestone, as was first defined by van de Graaff(1971a), has a early Moscovian age (VereiskianKashirskian), and provides a facies model for most of the Carboniferous limestones in the Cantabrian Mountains. A boundstone of auloporoids and chaetetids has been identified in the level 16 of van de Graaff (1971a), which Mingewen (2001) denominated as a biostrome of chaetetids with syringoporids and rugose corals and which was sampled for this study.

Ribadesella section (Calizas del Cuera Formation, Picos de Europa Unit). This section was first described by Rodríguez et al. (1997) and Fernández (1995). In this quarry subhorizontal marls and limestones crop out. The section begins with 8-10 m of silty limestones and marls containing common dissepimented solitary and colonial Rugosa and chaetetids, and scarce auloporids. This interval is overlain by $10-12 \mathrm{~m}$ of massive well-bedded limestone containing less abundant corals, which extends to the top of the quarry. Chaetetids are usually represented by large colonies encrusting brachiopods, rugose corals and tabulate corals. Most of them show a subspherical shape. Auloporids were less abundant and usually grew on lateral surfaces of large solitary corals whereas the rugose corals are very abundant and show little or no transportation. The presence of fusulinids in these beds establishes an Early Moscovian age (Rodríguez et al., 1997).

The Vergaño Formation (Pisuerga Carrión Unit) was defined by van de Graaff (1971b) as having a lower part of cross-stratified sandstones-shales with thin interbedded layers of mudstone and sandstone, limestones, and a turbidite bed. Three members of limestone can be recognized in this formation, Socavón Limestone (Podolskian), Cotarraso Limestone (Podolskian-Myachkovian) and the Sierra Corisa Limestone member (Myachkovian). These limestone members form three superstructures denominated as the Casavegas Syncline, Redondo Syncline and Castillería Syncline (Wagner et al., 1983; Wagner 2009).

van de Graaff (1971b) described the facies from the Vergaño Formation and mentioned the presence of auloporid cor- als in the limestones facies from Pico Guillermo, Peña Abismo, Cabramocha, Vergaño, Celada de Roblecedo, Tremaya, Casavegas, Peña Tres Mares, and Peña Agujas sections.

Three sections were sampled from this study: Celada de Roblecedo Sur, Pico Guillermo and Este de Camasobres.

Celada de Roblecedo Sur: This section is located in the Celada de Roblecedo Anticline between the Redondo Syncline and the Castillería Syncline. It is Late Moscovian (Myachkovian horizon) in age.

Este de Camasobres: Located in the Casavegas Syncline and corresponds with a small section described by Boll (1985) where abundant rugose corals occur with auloporids and chaetetids. It is Middle Moscovian (Kashirian-early Podolskian horizons) in age.

Pico Guillermo: Located in the Redondo Syncline. It is a large calcareous olistolith that was described by van de Graaff (1971b) and contains small colonies of auloporid corals in growth position. It is Middle Moscovian (Kashirianearly Podolskian) in age.

Prioro limestones (Pando Formation, Esla Nape): The synorogenic sediments of the Esla Nappe form a succession that exceeds $5 \mathrm{~km}$ in thickness in some sectors of the nappe, but generally presents strong changes of thickness, some discordances and lateral changes of facies, as a consequence of the synsedimentary tectonic activity (Alonso, 1989). In the first stage (Bashkirian-Moscovian) the succession has a marine character with deposits of talus (turbidites, olistostromes, shales with pebbles, etc). In this succession, a carbonate lithosome denominated as the Mesao Limestone (van Loon, 1971) is conspicuous. It consists of an alternation of limestones and calcareous mudstones. Bioclastic limestones occur as well as biogenic banks. The biogenic banks are mainly constructed by algae, but corals, brachiopods, crinoids, and fusulinids are almost always present. The bioclastic limestones consist mainly of transported crinoidal fragments, but brachiopods, corals, fusulinids, and even plant remains occur as well. These materials were dated as from fusulinid assemblage as Westphalian C (early Podolskian) by van Loon (1971).

The biogenic banks have been sampled for this study both in the south flank and in the north flank of the Pando Syncline where the thickness of the limestones is much greater.

Playa de la Huelga (Calizas del Cuera, Picos de Europa Unit): This section is exposed along the cliffs of eastern Asturias from San Antolín Beach to the village of Hontoria. Villa (1995) dated the levels sampled in this work as early Podolskian - late Myachkovian. Rodríguez (1984) studied the coral faunas, mainly focused in the Rugosa specimens. In a later taxonomical study focused in tabulates, Rodríguez and Ramírez (1987) described three new taxa that occur in the Playa de la Huelga section. Two cerioid-phaceloid forms assigned to Neomultithecopora cantabrica and N. submassiva, and a phaceloid-bushy form denominated as Multithecopora hontoriense. The Pennsylvanian materials that provided the subject of the study (interval of latest Podolskian or earliest Myachkovian age) are composed of $c a .100 \mathrm{~m}$ of massive 


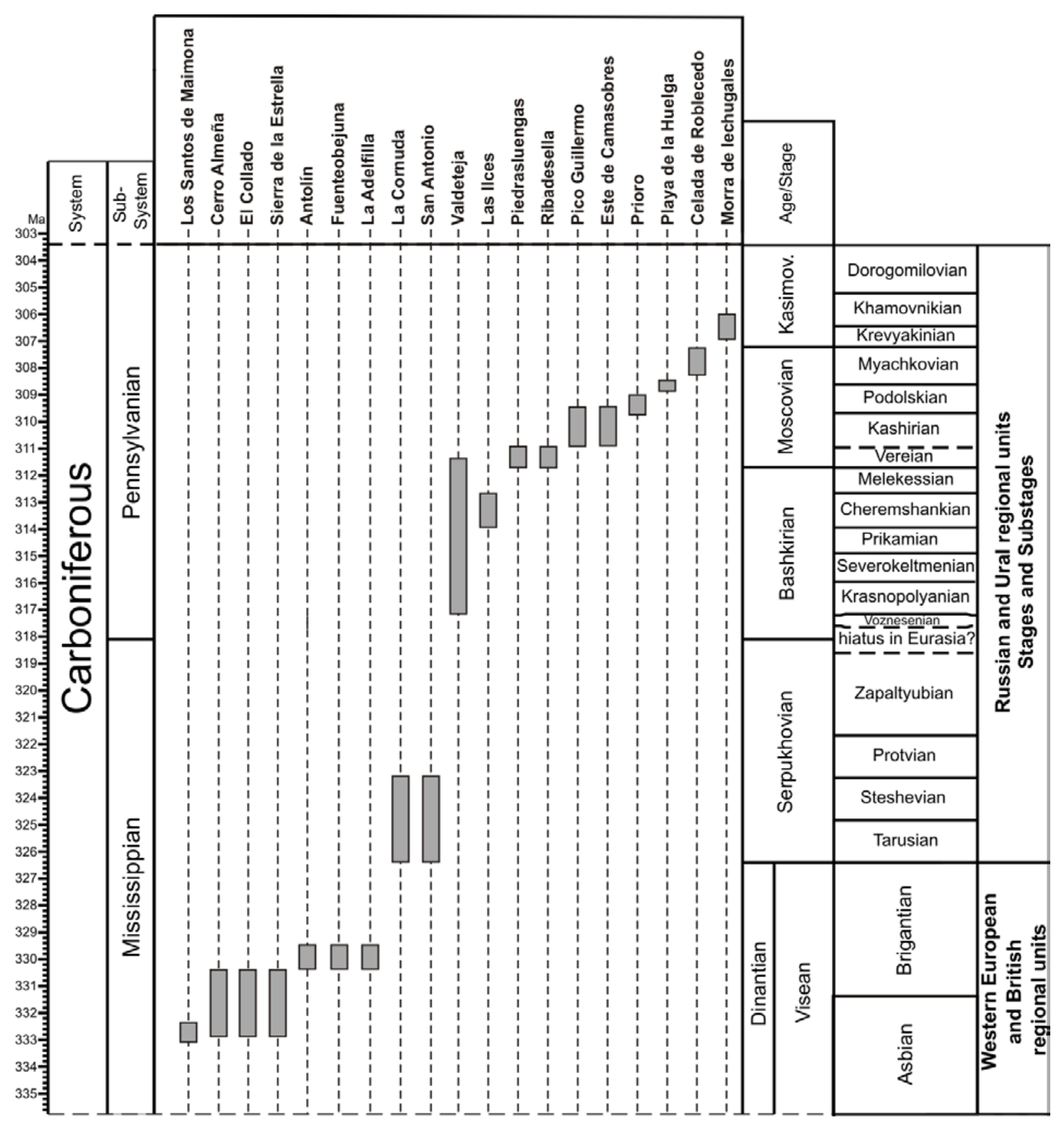

Fig. 4.- Temporal distribution of the carbonifeours setions sampled in Iberian Peninsula.

bioclastic limestones, which present interbedded marls and shales and occasionally sandstones. Minwegen (2001), described the microfacies and bioconstructions found in Playa de la Huelga section (Hontoria I sensu Minwegen, 2001). She described the bioconstruted facies as reef-mound facies. These beds are dominated by syringoporoid masses in growth position, associated with bryozoa, abundant brachiopods, calcareous algae, chaetetids, and rugose corals.

In addition, syringoporoids cited and figured in the Picos de Europa Unit, at Morra de Lechugales section in Cantabria province (Minwegen, 2001; Martínez-Chacón et al., 2001; Merino-Tomé et al., 2009) have been also identified from the bibliography. The specimens sampled in the Cantabrian zone range from early Bashkirian to late Moscovian in age. The inclusion of the Morra de Lechugales section extends the record to early Kasimovian.

\subsection{Introduction to Auloporida}

Two superfamilies were identified in the record for Auloporida Sokolov, 1947 order; Auloporicae Milne-Edwards and Haime, 1851 and Syringoporicae de Fromentel, 1861; twenty families were recognized, of which twelve have been recorded in the Carboniferous period: Auloporidae Milne-Edwards and Haime, 1851; Pyrgiidae, de Fromentel, 1861; Romingeriidae, Sokolov, 1950; Aulocystidae, Sokolov, 1950; Sinopo- 
ridae, Sokolov, 1955; ?Khmeriidae, Montanaro-Gallitelli, 1954; Syringoporidae, de Fromentel, 1861; Tetraporellidae, Sokolov, 1950; Multithecoporidae, Sokolov, 1950; Roemeriidae, Počta, 1904; Thecostegitidae, de Fromentel, 1861 and Gorskyitidae Lin, 1963.

Auloporida formed arbustive or fruticose colonies with proximal corallites commonly prostrate or adherent to other biogenic or inorganic remains; may have erect corallites (fasciculate) or branched (dendroid) and more rarely cerioid. They show diverse forms: tubular, horned, cylindrical or prismatic. This order could show mural pores or connecting tubuli (e.g. Syringoporicae); the septa are represented by longitudinal rows of commonly fine spines, and the tabula are very sparse or even absent to numerous, complete or incomplete, with a syrinx in most Syringoporicae. The increase is lateral and commonly basal (cf. Hill, 1981).

\subsection{Systematics and classification}

There are no useful common criteria to establish the main features for the auloporid taxonomy to different levels. Those features depend on the subjectivity of the author and the superfamily involved. In Auloporicae the most commonly used criterion is the general morphology, the growth habit and, to a lesser degree, the presence and morphology of tabulae and septal spines. In Syringoporicae, more diverse criteria have been used. Nelson (1977) used four parameters in the taxonomy of syringoporid corals; two of which are the corallite diameter and the frequency of corallites (number of corallites that occur within a certain area). This author suggests that these parameters are very important in defining species and that both are, more or less, independent of the environment. Nelson (1977) suggests also two other parameters, the type of tabular pattern and the wall thickness, which are significant in defining genera. Other authors, such as Nowinski (1991) and Niko (1998), have employed the frequency or distance between corallites. Tchudinova (1975), Sando (1984) and Nowinski (1991) used not only the corallite diameter and the distance between corallites, but also the wall thickness, diameter of connecting tubes, distance between connecting tubes, distance between tabulae, diameter of axial canal or lumen and the amount of septal spines. These additional characters also were used by Rodríguez and Ramirez (1987) along with the diameter of corallite and thickness. These criteria could be used in those genera that present abundant tabulae and connecting structures, but cannot be used as a systematic feature in all auloporid genera.

Tchudinova (1980) presented a study on the morphogenesis of Syringoporidae, which shows a series of characters that occur in different genera through time. These are: microstructure of corallite wall, presence of lamellar or fibrous sclerenchyme and presence of septal spines, connecting elements and tabulae.

In this study we follow the taxonomical characters proposed by Tchudinova (1980): microstructure, septal spines, and tabulae, together with the corallite diameter, lumen diameter, and their relationship (diameter/lumen), which helps in the identification of some genera such as Multithecopora and Sinopora. The frequency or space between corallites, as suggested by Nelson (1977), is an acceptable criterion for use in Syringoporidae, but not in Multithecoporidae and Sinoporidae, because these families show plasticity in growth and the substrate and environment control the growth of the colonies. The morphology of the colony and the morphology of the corallite only have been considered for the Auloporicae taxa. The kind of septal spines used by Tchudinova (1980) are also used in Scleractinian corals and compiled by Hill (1981). However, in our opinion, this criterion could cause some problems in the classification of tabulate corals. For this reason, we use quantitative criteria (abundant, common or scarce), distribution (sparse, in rows or random) and form (acute or blunt) to describe the septal spines. Occasionally, septal spines are very scarce or absent, but the wall presents undulations in the sclerenchyma as septal projections.

Sando (1984) undertook a biostratigraphic study on syringoporid corals from the Western Interior Region, USA and he grouped all the syringoporoids in morphogroups. In the absence of previous taxonomical studies, this methodology has been used in this study, subdividing the genera into morphotypes. Due to the plastic morphology and growth habit of auloporidae, these morphotypes may be species or subspecies (ecophenotypes) or groups of species, and need to be analyzed deeper in the future.

The Carboniferous auloporids of the Iberian Peninsula include nine nominal genera and have been divided into 18 morphotypes and two species, which are based on the morphologic criteria documented above (Table 1).

\subsubsection{Mississippian taxa}

The Mississippian samples have been located in the OssaMorena Zone, and five genera have been identified: Multithecopora Yoh, 1927; Syringopora Goldfuss, 1826; Syringoalcyon Termier and Termier, 1945; Cladochonus McCoy, 1847 and Roemeripora Kraicz, 1934. Table 1 shows the main taxonomical characters of each genus identified.

Multithecopora is the most frequent genus in the Iberian Peninsula. We have identified four morphotypes in the OssaMorena Zone: Multithecopora sp. A, sp. B, sp. C and sp. H.

Multithecopora sp. A shows a larger size than the other Mississippian morphotypes of Multithecopora (avg. 1.96 $\mathrm{mm}$-range 1.47-2.85 $\mathrm{mm}$ in diameter; Table 1) and presents well developed septal spines, which show acute morphology (Fig. 5). This morphotype is present in five sections of the Ossa-Morena Zone (Antolín-1, Sierra de la Estrella, Fuenteobejuna, Los Santos de Maimona and El Collado sections) ranging in age from middle-late Asbian to early Brigantian.

Multithecopora sp. B is quite similar to Multithecopora $\mathrm{sp.}$ A, but differs in the diameter (1.06 mm versus $1.96 \mathrm{~mm}$ ). This morphotype occurs in the Antolín-1 and Fuenteobe- 

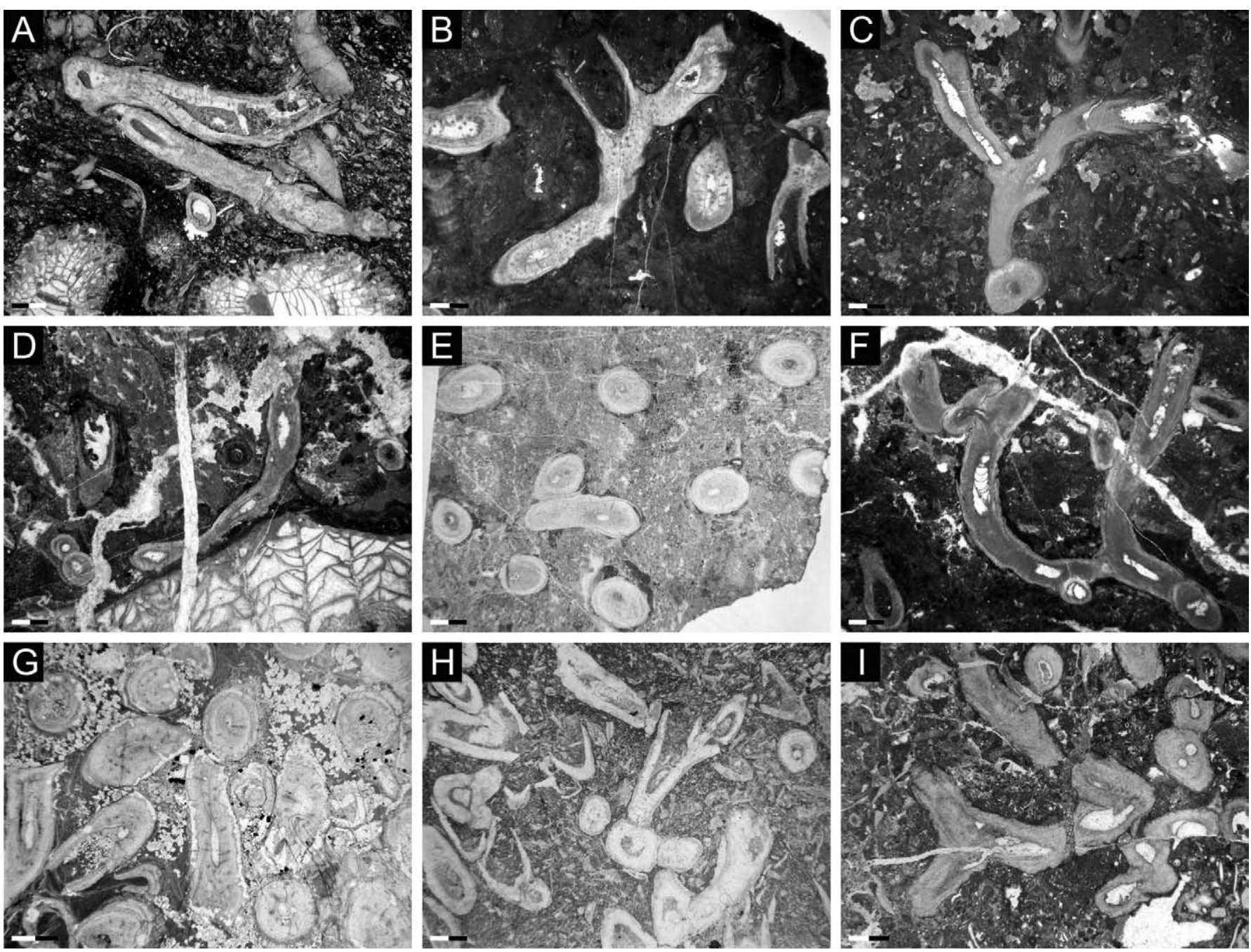

Fig. 5.- Multithecopora sp. A. A) Fragments of corallites in storm beds from El Collado Section. B-C) Branched corallites from Antolín section on thrombolitic-microbial texture. Note the growth of automicrite around the corals and the pseudostromatactoid cavities in B. D-F) Sierra de la Estrella section. D) Encrusting habit of Multithecopora sp. A on a rugosan. E-F) Phaceloid development, parallel with an initial reptant growth. G) Multithecopora sp. A in Los Santos de Maimona section growing in a reef-flat facies. Note the dolomite development around the corallites. H) Reworked facies in Los Santos de Maimona section. Note the fragmentation and abrasion of the corallites. I) Multithecopora sp. A in shallow-water facies from Fuenteobejuna section. Note the brecciation and the reworked corallites. Scale bar is $2 \mathrm{~mm}$.

juna sections and has a early-middle Brigantian distribution (Fig.6A-B).

Multithecopora sp. C shows a more bushy growth than the previous morphotypes, forms better developed colonies, and the corallites present less septal spines (Fig. 6C-D). This morphotype occurs in the early Brigantian from El Collado (zone 16 of Mamet, 1974). Multithecopora sp. A, B and C occur only in the Viséan.

Multithecopora sp. H shows a phaceloid growth habit and encrusting on rugose corals. Their characteristics are common in Multithecopora genera: the diameter/lumen rate and the dimensions, the presence of septal spines, and a colonial development forming small bushy colonies (Fig. 6E-F). This morphotype is known only from the Serpukhovian (Pendleian Stage, Table 2).

Another significant genus in the Viséan recorded from the Ossa-Morena Zone is Syringopora. Two morphotypes have been recognized: Syringopora sp. A and Syringopora sp. B. Both morphotypes show the main characteristics of Syringopora. The differences between them are that Syringopora sp. B is larger than Syringopora sp. A, and has a higher lumen diameter. Syringopora sp. B shows a fasciculate development, with less density of corallites and branched colonies (Fig. 7A-D). Syringopora sp. A shows a palisade development with a high density of corallites (Fig. 7E-F). The morphology of the corallites of Syringopora sp. A is more irregular than that of the morphotype B, which present a more cylindrical development. Syringopora sp. A occurs only in the Los Santos de Maimona Basin and in Los Santos and Cerro Almeña sections of late Viséan (middle-late Asbian) age. Whereas Syringopora sp. B occurs in the Guadiato Area, and more specifically in the Antolín and La Adelfilla sections and is of late Viséan (early Brigantian) age. 

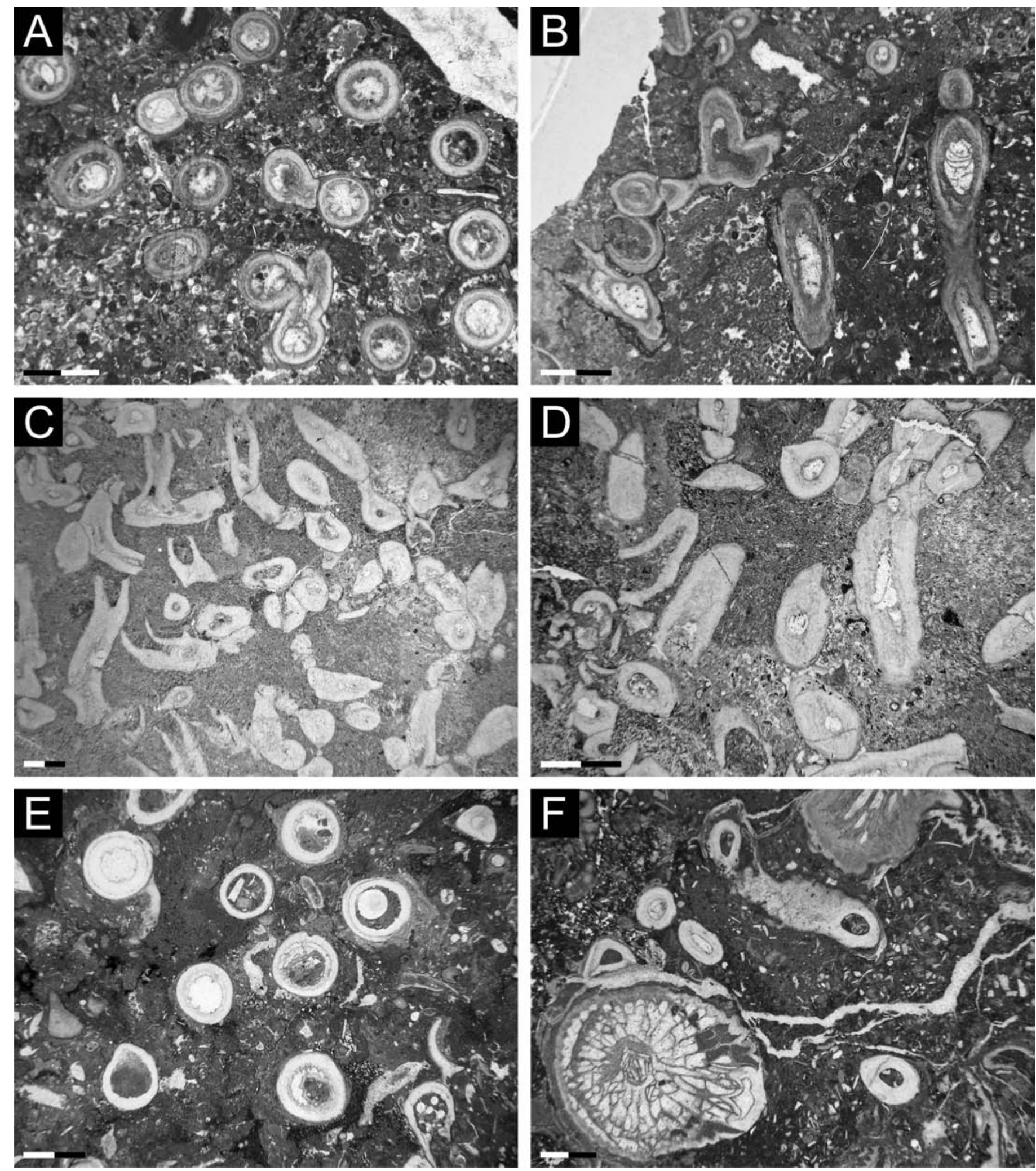

Fig. 6.- A-B) Multithecopora sp. B in Fuenteobejuna section. Note the abundance and acute development of the septal spines in A and the presence of incomplete tabulae in B. C-D) Multithecopora sp. C corallites in El Collado section. Note that some branches are reworked and transported whereas others are in growth position, like in D. E-F) Multithecopora sp. H in La Cornuda section. E) Note the small and scarce septal spines and the parallel (phaceloid) development of the corallites. This illustration shows a superficial section of the calices. F) This morphotype is encrusting a rugose coral. Scale bar is $2 \mathrm{~mm}$. 
Syringoalcyon is another common genus in Ossa-Morena. It has been recorded in the Los Santos de Maimona and Cerro Almeña sections with a distribution of Asbian-Brigantian. This genus presents distinctive epithecal scales and shows characteristics very similar to Syringopora (Fig. 7G-I). For this reason some authors such as Hill (1981) and Tourneur et al. (1995) identified it with Syringopora. Its distribution is middle Asbian. The epithecal scales of the samples of Los Santos de Maimona Coal Basin do not show a dense packing and are thinner than those described in the literature.

Roemeripora sp. occurs only in the Fuenteobejuna section as massive cerioid colonies, where the corallites show a dense packing with prismatic and irregular forms, with abundant septal spines and connecting tubuli (Fig. 8E-F). It occurs from late Asbian to early Brigantian (Cózar et al., 2007).

Cladochonus sp. A is one of the two morphotypes (A and B) that occurs in the Iberian Peninsula. It shows an initial tubular development with a secondary globular enlargement and "diaphragms" between corallites as well as the lack of tabulae and spines (Fig. 9C-D). This morphotype occurs in the lower levels of the El Collado section, which is uppermost Asbian in age (Zone 15 of Mamet, 1974 biostratigraphy).

\subsubsection{Pennsylvanian taxa}

On the other hand, the Pennsylvanian samples collected in the Cantabrian Zone yielded six nominal genera: Multithecopora Yoh, 1927; Neomultithecopora Lin, 1963; Sinopora Sokolov, 1955; Cladochonus McCoy, 1847, Aulopora Goldfuss, 1829 and Mastopora? Sokolov, 1952. Table 1 shows the main taxonomical characters of each genus identified in this zone.

Four morphotypes and one nominal species of Multithecopora have been recognized in the Cantabrian Zone: Multi-
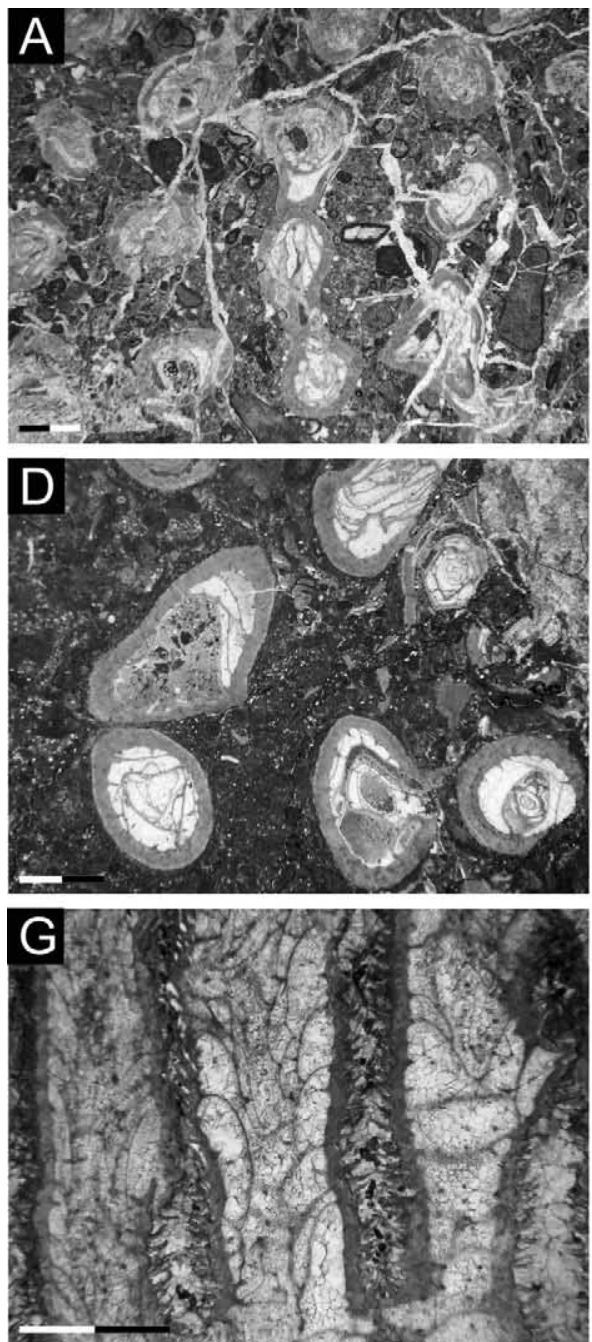
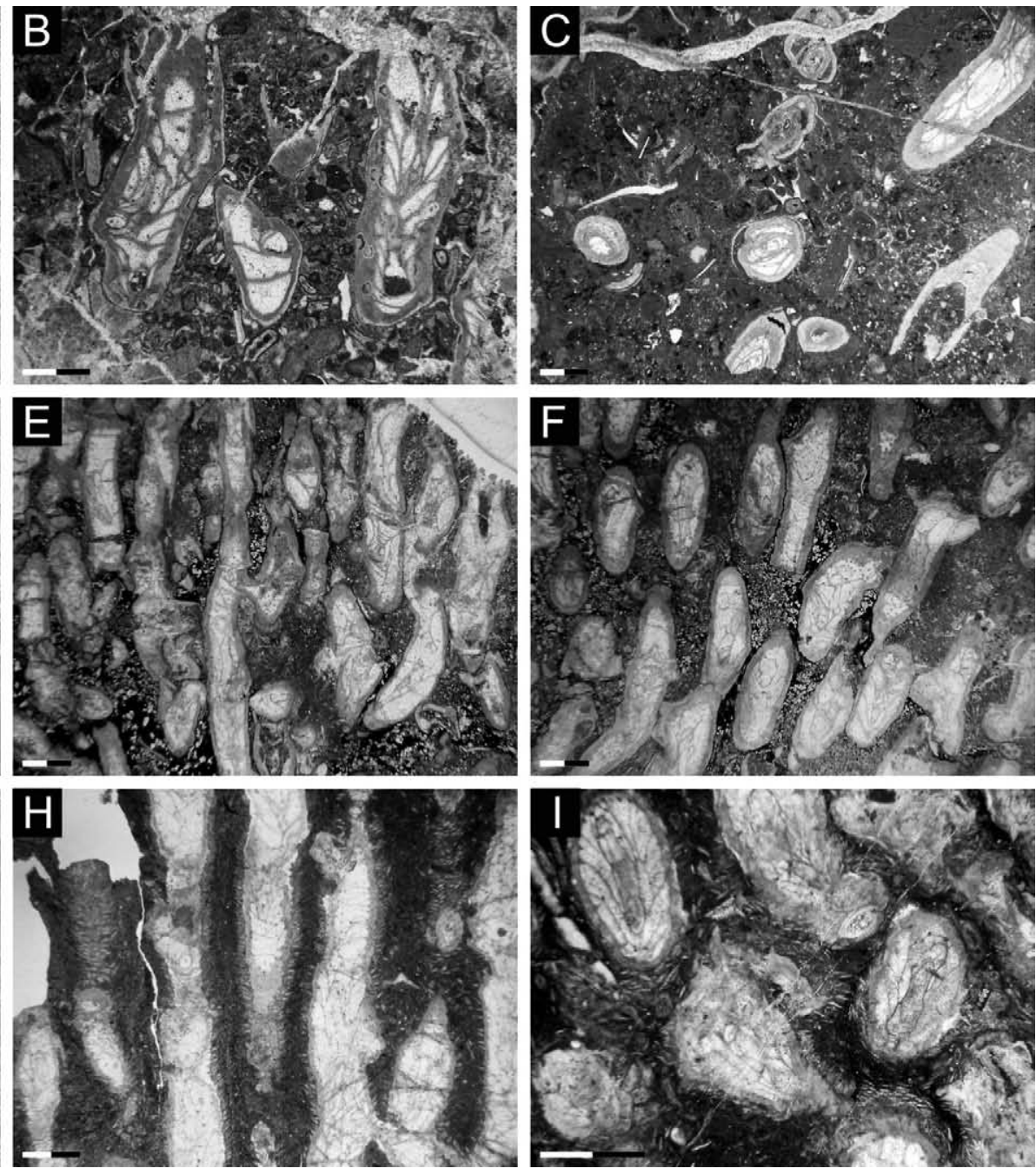

Fig. 7.- A-B) Syringopora sp. B from La Aldelfilla section in a matrix with cortoids and peloids. C-D) Branched development of Syringopora sp. B from Antolín section in microbial texture. E-F) Syringopora sp. A from Los Santos de Maimona section. Note the palisade development of the colony. G-I) Syringoalcyon sp. G) Detail of the epithecal scales on the corallites of Cerro Almeña section. Note the sparite cement between the corallites in reef-flat facies. H-I) Syringoalcyon sp. from Los Santos de Maimona section. Note the dense packing of the epithecal scales around the corallites in I and the growth in palisade of this morphotype in H. Scale bar is $2 \mathrm{~mm}$. 
thecopora sp. D, Multithecopora sp. E, Multithecopora sp. F, Multithecopora sp. G, and Multithecopora hontoriense Rodríguez and Ramírez, 1987.

Multithecopora sp. D shows phaceloid colonies composed of small corallites that show septal projections and have a well-developed inner fibrous domain or an alternation of fibrous and lamellar domains. The growth pattern is prostrate in early stages, but later the corallites develop an erect growth, with subsequent budding in some cases (Fig. 10AB). This morphotype occurs in the Valdeteja section at higher levels than the "Cladochonus band" of Winkler Prins (1971), which could occur from early Bashkirian? to early Moscovian rocks (Villa et al., 2001), but it is more probable that it occurs in a middle Bashkirian to early Moscovian (Tashatinian - Vereian) horizon.

Multithecopora sp. E shows diameter and septal projections similar to the previous morphotype but presents some differences, such as the microstructure (only three domains, mainly lamellar), and the growth habit (phaceloid and bushy). This morphotype grows encrusting other organisms, such as rugose corals or Chaetetes. The corallite length is very short, showing an open calyx almost from the beginning of the offsetting (Fig. 10C-F). This morphotype occurs in two sections in the Cantabrian Zone; in the Las Ilces section, middle Bashkirian in age (Tashatinian horizon, Coronado, 2008) and in the Piedrasluengas section, early Moscovian in age (Vereian horizon, van der Graaff, 1971a).

Multithecopora sp. F is similar to the previous morphotype; the differences are in the growth habit; this morphotype is reptant or rarely bushy, shows a smaller diameter and smaller septal protrusions (Fig. 11A-B). This morphotype only occurs in the Este de Camasobres section that is late Moscovian in age (Kashirian horizon, van der Graaff (1971b), Westphalian C sensu Boll, 1985).

Multithecopora sp. G shows a bushy development of the colonies and a smaller diameter than previous morphotypes. This morphotype presents scarce septal spines that are small and short (Fig. 11C-D). The colonies are composed of many corallites and grew encrusting on chaetetids and other bioclasts. This morphotype only occurs in the Prioro section that is late Moscovian in age (Podolskian - early Myachkovian).

Multithecopora hontoriense presents a larger diameter than other Multithecopora of the Cantabrian Zone; they built erect, densely packed or branching, bushy colonies (Fig. 12A-H). The corallites show scarce septal spines but frequent septal projections that offer an undulating microstructure. This morphotype presents fibrous inner and outer layers and, sometimes, a thin fibrous middle layer. It is present in two sections of the late Moscovian. It occurs in the Pico Guillermo section that is Kashirian-Podolskian in age and in the Playa de la Huelga section that is PodolskianMyachkovian in age.

The taxon Neomultithecopora cantabrica shows phaceloid to submassive colonies with lateral increase. The corallites show circular to prismatic sections, sometimes sharing the wall with neighbouring corallites (Fig. 8A-D). This taxon shows a thick wall with abundant septal spines and frequently connecting tubuli. The tabulae are variable in shape (curved, horizontal or infundibuliform). This genus is similar to Multithecopora in the structure of the wall. It shows alternating fibrous and lamellar layers with higher development of the lamellar layers. This species occurs in two sections, in the Playa de la Huelga, where it occurs associated with chaetetids and rugose corals and in the Prioro section, where it appears associated with chaetetids and Multithecopora sp. G and has an late Moscovian (Podolskian-Myachkovian) age.

Sinopora also occurs in the Celada de Roblecedo section and shows a bushy colonial morphology with cylindrical corallites similar to Multithecopora, but with deeper calices and absent septal spines. The tabulae are rare (scarce or absent) and concave (Fig. 11E-F). The age of this morphotype is late Moscovian (Myachkovian).

Cladochonus sp. B occurs in the Valdeteja section. This morphotype presents the classical features of this genus, as compiled by Hill (1981) and later Stasinska (1982): coral prostrate, which in distal parts presents erect branches that seem forked, with a characteristic growth in zigzag, inner "diaphragms" between corallites as well as the lack of the septal apparatus, and scarce curved tabulae (Fig. 9A-B). The level of Cladochonus is early Bashkirian in age (Akavasian horizon, Villa et al., 2001).

Aulopora is represented by two morphotypes (Aulopora sp.A, sp. B), which occur in the same locality (Ribadesella section, early Moscovian, Vereyian horizon). Both $A u$ lopora morphotypes show adherent colonies with cornute corallites joined in anastomosing chains; the calices show a conical shape, basal-lateral increase, and moderately thick walls (Fig. 13).

Aulopora sp. A shows a thick wall similar to Multithecoporidae, but it does not show septal spines and the microstructure is poorly preserved. However, a fibrous domain and an inner and thicker homogeneous lamellar domain are distinguished (Fig. 13A-B). The tabulae are curved (concave and convex) and frequent.

Aulopora sp. B shows a more open calyx lumen and thinner wall than Aulopora sp. A. Septal spines are absent and tabulae are infundibuliform as in Syringopora. The microstructure is composed of an outer fibrous layer more developed than that in Aulopora sp. A (Fig. 13C-F).

Two colonies of Mastopora? sp. show reptant and densely packed colonies, which form continuous encrusting sheets. Occasionally, it may form a globular shape, when the successive sheets are joined. Although the collected samples do not display the typical mammilliform shape of Mastopora corallites, the growth habit and the presence of sheet-like structures point to this genus. Two colonies have been sampled in the Playa de la Huelga section. The calices are raised and present a small aperture and thick walls, but the relation- 

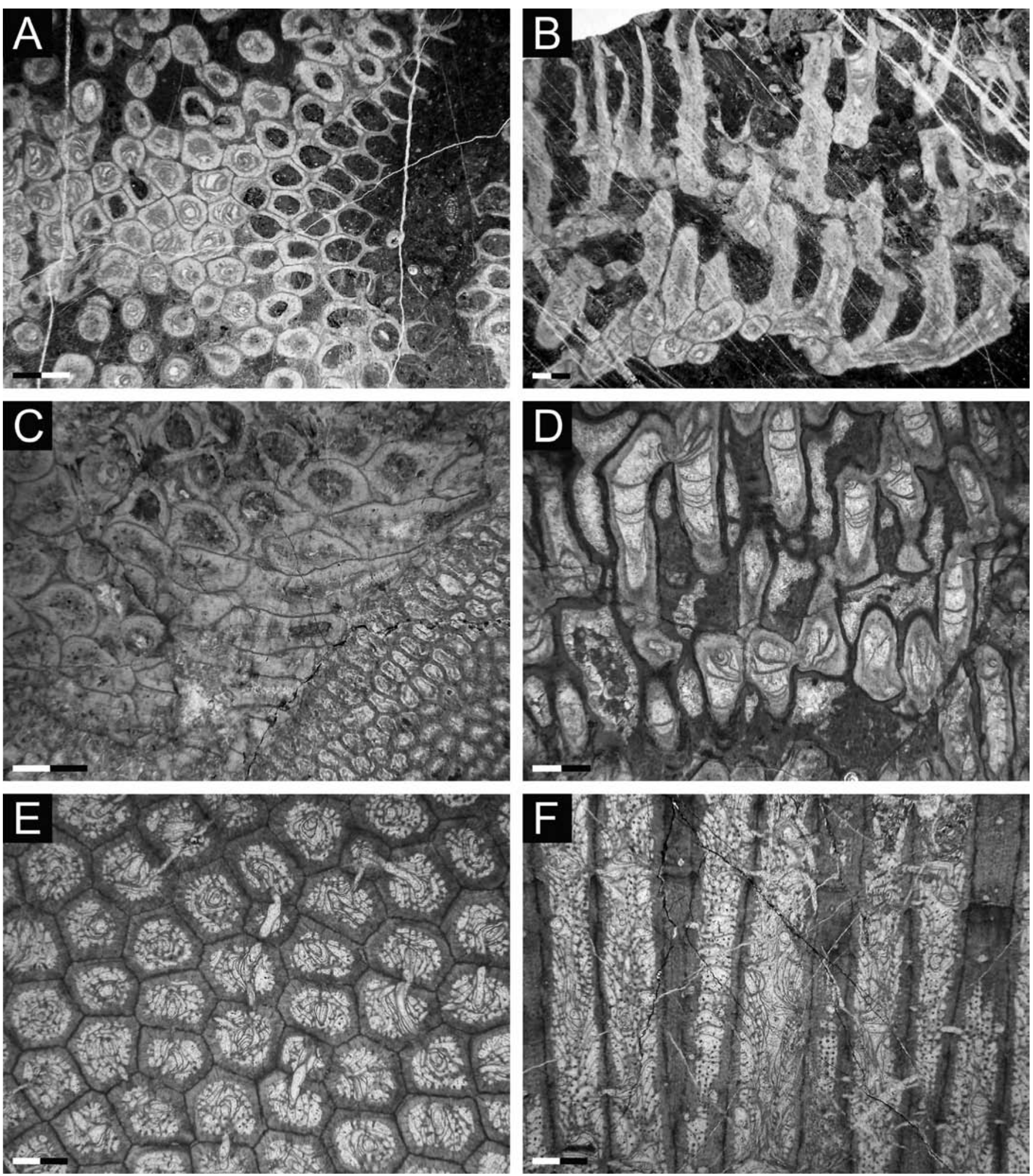

Fig. 8.- A-D) Neomultithecopora cantabrica Rodríguez and Ramírez, 1987. A-B) Samples from Prioro section. Note the massive-proximal and prismatic habit of the corallites in A. B) Reptant initial development of the colony and the vertical growth later. C-D) Samples from Playa de la Huelga section. C) Note the massive development of the colony that initially is encrusting a chaetetid. D) Phaceloid habit with connecting tubuli between corallites. E-F) Roemeripora sp. from Fuenteobejuna section. Note the massive and prismatic development of the corallites and the communication between them through connecting tubuli. Scale bar is $2 \mathrm{~mm}$. 

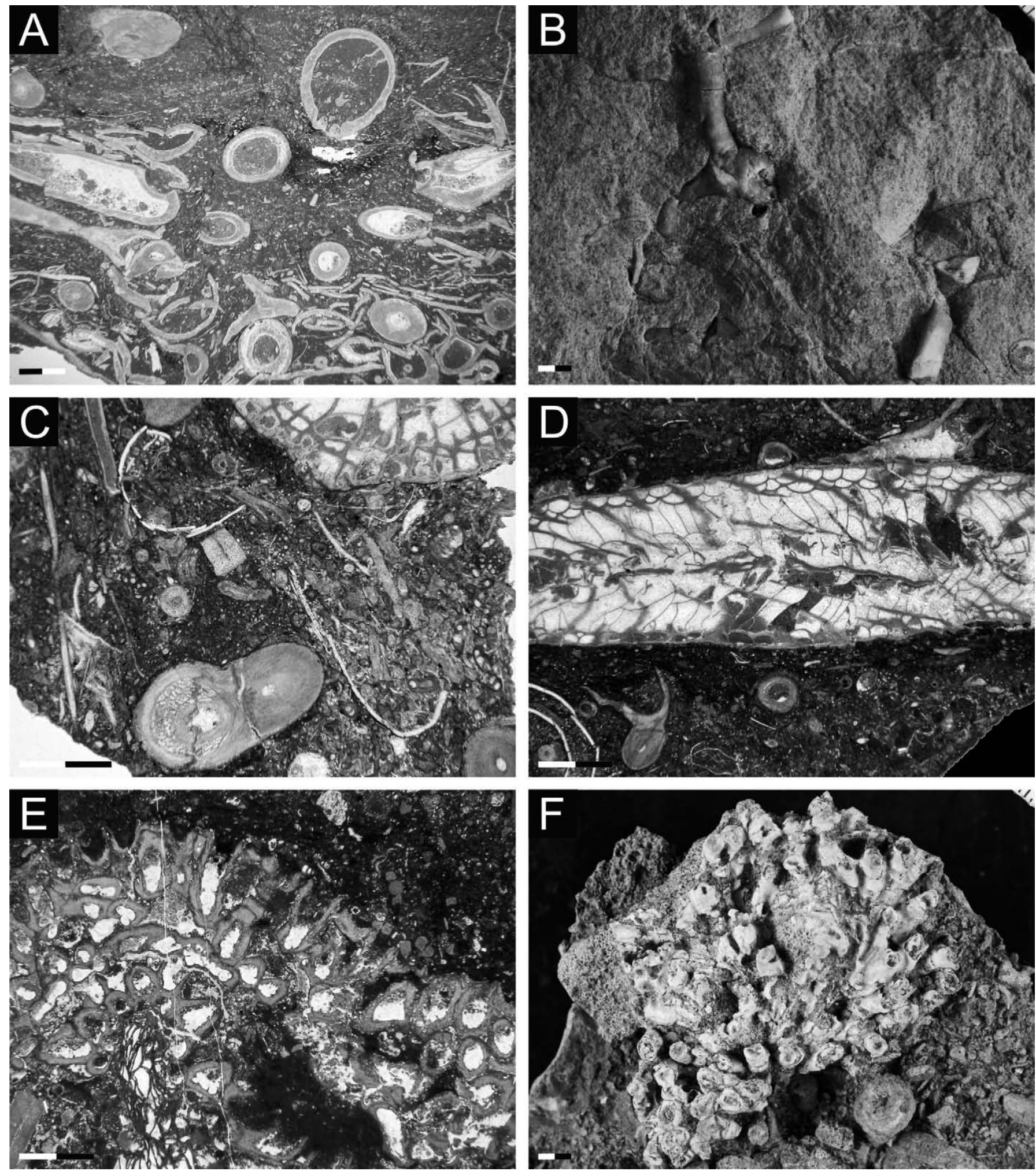

Fig. 9.- A-B) Cladochonus sp. B from Valdeteja section. A) Caldochonus wackestone with many corallites oriented in the bottom of the strata. B) Detail of zigzag development of three-dimensional sample on the bedding plane. C-D) Cladochonus sp. A from El Collado section. C) Note the diaphragm in the inner part of the calyx. D) Detail of Cladochonus encrusting a rugose coral in a storm bed. E-F) Mastopora? Detail of the colony in thin section. Note the septal spines and the open calices. F) Colony in the calcareous sandstone encrusting and being encrusted by bryozoans. Scale bar is $2 \mathrm{~mm}$. 


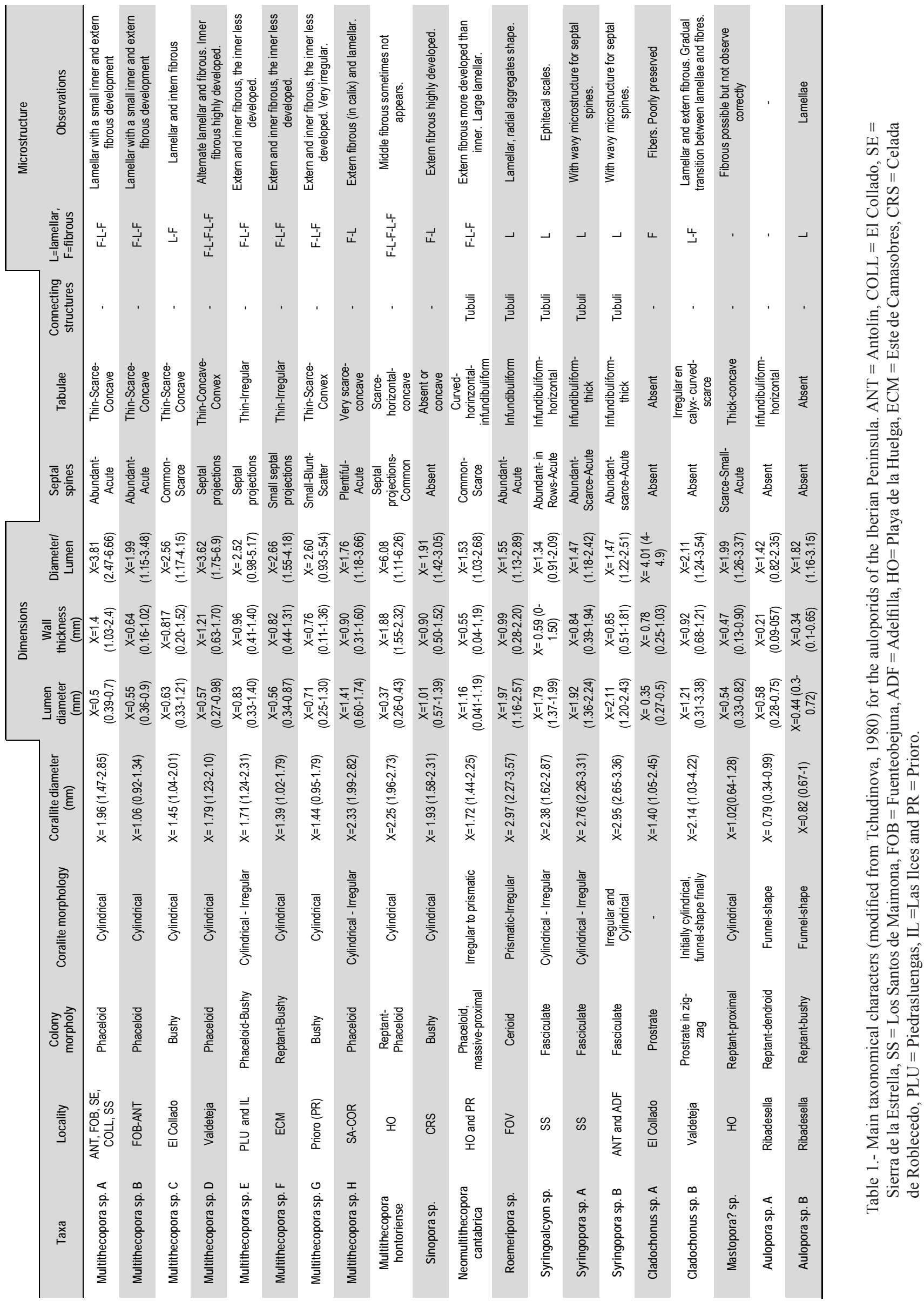




\begin{tabular}{|c|c|c|c|c|c|c|}
\hline Section & Facies and depositional texture & Geometry and lithology & Components & Depositional environment and characteristics & Morphotype & Age \\
\hline $\begin{array}{l}\text { Los Santos de } \\
\text { Maimona / Cerro } \\
\text { Almeña }\end{array}$ & $\begin{array}{l}\text { Boundstone (Framestone) of } \\
\text { Syringoporicae with packstone- } \\
\text { wackstone matrix }\end{array}$ & $\begin{array}{l}\text { Biostromal facies (masive } \\
\text { limestones and marls) }\end{array}$ & $\begin{array}{l}\text { Rugosans, brachiopods, molluscs, echinoderms, } \\
\text { trilobites, endothyrids, textularids, bryozoans, } \\
\text { calcareous algae. }\end{array}$ & $\begin{array}{l}\text { Reef flat. Near to shore. Shallow, highly to } \\
\text { moderately agitated water. Above or close to } \\
\text { effective fair-weather wave-base. Well-oxygenated, } \\
\text { normal marine. }\end{array}$ & $\begin{array}{l}\text { Multithecopora sp. A, } \\
\text { Syringoalcyon sp. \& } \\
\text { Syringopora sp. A }\end{array}$ & $\begin{array}{l}\text { late Visean (middle- } \\
\text { late Asbian) }\end{array}$ \\
\hline Sierra de la Estrella & $\begin{array}{l}\text { Micropeloidal Wackestone- } \\
\text { Boundstone (Framestone) of } \\
\text { Multithecopora }\end{array}$ & $\begin{array}{l}\text { Massive limestones-mound and } \\
\text { breccias }\end{array}$ & $\begin{array}{l}\text { Peloids, micropeloids. Aoujgalids, heterocorals, } \\
\text { rugosans, endothyrids, Girvanella, molluscs, } \\
\text { crinoids, Thartharella and bryozoans. }\end{array}$ & $\begin{array}{l}\text { Top of mud-mounds and limestone breccias. } \\
\text { Shallow to moderately deep subtidal conditions, } \\
\text { below fair-weather wave-base. Well-oxygenated, } \\
\text { normal marine. }\end{array}$ & Multithecopora sp. A & $\begin{array}{l}\text { late Visean (late } \\
\text { Asbian - early } \\
\text { Brigantian) }\end{array}$ \\
\hline EI Collado & Bioclastic wackestone-packstone & $\begin{array}{l}\text { Thin beds of limestones in a marls } \\
\text { succession. }\end{array}$ & $\begin{array}{l}\text { Bryozoans, bivalves, echinoderms, crinoids, } \\
\text { calcareous algae, Aoujgalids, rugose corals, } \\
\text { gastropods, trilobites, ostracods and foraminifers. }\end{array}$ & $\begin{array}{l}\text { Shallow carbonate platform. Near to shore. } \\
\text { Shallow water, highly to moderate agitate energy. } \\
\text { Between wave base and storm base. Well- } \\
\text { oxygenated, normal marine. }\end{array}$ & $\begin{array}{l}\text { Multithecopora sp. A \& } \\
\text { Cladochonus sp. A. }\end{array}$ & $\begin{array}{l}\text { late Visean (late } \\
\text { Asbian - early } \\
\text { Brigantian) }\end{array}$ \\
\hline El Collado & Bioclastic packstone-wackestone & Massive and bedded limestones & $\begin{array}{l}\text { Grapestones and peloids. Bryozoans, bivalves, } \\
\text { echinoderms, crinoids, calcareous algae, Aoujgalids, } \\
\text { rugosans, gastropods, trilobites, ostracods and } \\
\text { foraminifers. }\end{array}$ & $\begin{array}{l}\text { Shallow carbonate platform. Near to shore. } \\
\text { Shallow water, highly to moderate agitates energy. } \\
\text { Between wave base and storm base. Well- } \\
\text { oxygenated, normal marine. }\end{array}$ & Multithecopora sp. C & $\begin{array}{l}\text { late Visean (early } \\
\text { Brigantian) }\end{array}$ \\
\hline Antolín & $\begin{array}{l}\text { Micropeloidal Mudstone-Wackestone } \\
\text { / Boundstone (Framestone) of } \\
\text { Multithecopora with cryptalgal } \\
\text { texture (Thrombolitic micrites) / } \\
\text { Bioclastic packstone }\end{array}$ & $\begin{array}{l}\text { Massive limestones-mound and } \\
\text { breccias }\end{array}$ & $\begin{array}{l}\text { Peloids, micropeloids, ooids. Aoujgalids, } \\
\text { heterocorals, rugosans, endothytirids, Girvanella, } \\
\text { molluscs, crinoids, Thartharella and bryozoans. }\end{array}$ & $\begin{array}{l}\text { Patch-reef to reef-mounds and talus facies. } \\
\text { Shallow to moderately deep subtidal conditions, } \\
\text { below fair-weather wave-base. Well-oxygenated, } \\
\text { normal marine. }\end{array}$ & $\begin{array}{l}\text { Multithecopora sp. A, } \\
\text { Multithecopora sp. B \& } \\
\text { Syringopora sp. B }\end{array}$ & $\begin{array}{l}\text { late Visean (early } \\
\text { Brigantian) }\end{array}$ \\
\hline Fuenteobejuna & $\begin{array}{l}\text { Boundstone of Multithecopora with } \\
\text { micritized grains }\end{array}$ & Massive limestones with breccias & $\begin{array}{l}\text { Peloids, micropeloids, ooids, coated grains and } \\
\text { lithoclasts. Rugose corals, ostracods, foraminifera, } \\
\text { bryozoans, gastropods,crinoids, brachiopods, } \\
\text { Aoujgalids, other calcareous algae, cyanobacteria. }\end{array}$ & $\begin{array}{l}\text { Near to shore. Shallow, highly to moderately } \\
\text { agitated water. Above or close to effective fair- } \\
\text { weather wave-base. Possibly vadose environment. }\end{array}$ & $\begin{array}{l}\text { Multithecopora sp. A, } \\
\text { Multithecopora sp. B \& } \\
\text { Roemeripora sp. }\end{array}$ & $\begin{array}{l}\text { late Visean (early } \\
\text { Brigantian) }\end{array}$ \\
\hline La Adelfilla & $\begin{array}{l}\text { Rudstone/ Boundstone (bafflestone) } \\
\text { of Syringopora / Boundstone } \\
\text { (Bafflestone) of rugose corals }\end{array}$ & Massive bioclastic limestones & $\begin{array}{l}\text { Micropeloids, ooids, chaetetids, brachiopods, } \\
\text { rugosans, foraminifers, bryozoans, molluscs, } \\
\text { echinoderms. }\end{array}$ & $\begin{array}{l}\text { Near to shore. Shallow, highly to moderate agitated } \\
\text { water. Between wave base and storm base. Well- } \\
\text { oxygenated, normal marine. }\end{array}$ & Syringopora sp. B & $\begin{array}{l}\text { late Visean (early } \\
\text { Brigantian) }\end{array}$ \\
\hline $\begin{array}{l}\text { La Cornuda / San } \\
\text { Antonio }\end{array}$ & $\begin{array}{l}\text { Micropeloidal mudstone-wackestone } \\
\text { / Boundstone of Multithecopora / } \\
\text { Oncoidal packstone/ }\end{array}$ & $\begin{array}{l}\text { Massive limestone with dome } \\
\text { shape }\end{array}$ & $\begin{array}{l}\text { Micropeloids and peloids, small bioclast fragments, } \\
\text { rugosans, chaetetids, bryozoans, calcareous algae, } \\
\text { cyanobacteria, crinoids, brachiopods, gastropods, } \\
\text { and oncoids in some facies. }\end{array}$ & $\begin{array}{l}\text { Mud-mounds to Reef-mounds and associated } \\
\text { facies. Near to shore. Shallow, highly to moderate } \\
\text { agitate energy. Between wave base and storm } \\
\text { base. Well-oxygenated, normal marine. }\end{array}$ & Multithecopora sp. H & $\begin{array}{l}\text { Serpukhovian } \\
\text { (Pendleian) }\end{array}$ \\
\hline Valdeteja & Cladochonus wackestone & Thin beds of marls and limestones & $\begin{array}{l}\text { Terrigenous clasts and small fragments of bioclasts, } \\
\text { rugosans, other tabulate corals(Pseudofavosites), } \\
\text { crinoids and brachiopods remains. }\end{array}$ & $\begin{array}{l}\text { Shallow carbonate platform, with terrigenous influx. } \\
\text { Near to shore. Shallow, highly to moderate agitated } \\
\text { water. Between wave base and storm base. Well- } \\
\text { oxygenated, normal marine. }\end{array}$ & Cladochonus sp. B & $\begin{array}{l}\text { early Bashkirian } \\
\text { (Akavasian) }\end{array}$ \\
\hline $\begin{array}{l}\text { Valdeteja - Las } \\
\text { Majadas }\end{array}$ & $\begin{array}{l}\text { Boundstone of Multithecopora with } \\
\text { peloidal matrix }\end{array}$ & Massive and bedded limestones & $\begin{array}{l}\text { Peloids, micropeloids. Thartharella, calcisphaeras, } \\
\text { foraminifers, Donezella, echinoderms, ostracods, } \\
\text { trilobites and bryozoans. }\end{array}$ & $\begin{array}{l}\text { Top of mound and associate facies. Shallow- } \\
\text { medium carbonate platform. Near to shore. } \\
\text { Shallow, highly to moderate agitate water. Between } \\
\text { wave base and storm base. Well-oxygenated, } \\
\text { normal marine. }\end{array}$ & Multithecopora sp. D & $\begin{array}{l}\text { middle Bashkirian - } \\
\text { early Moscovian } \\
\text { (Tashatinian- } \\
\text { Vereian) }\end{array}$ \\
\hline Las Ilces & $\begin{array}{l}\text { Boundstone of Multithecopora with } \\
\text { aoujgalids }\end{array}$ & $\begin{array}{l}\text { Massive limestones-mound and } \\
\text { bedded }\end{array}$ & $\begin{array}{l}\text { Peloids, micropeloids, intraclasts. Rugosans, } \\
\text { chaetetids, Donezella, Ungdarella, Petschoria, } \\
\text { echinoderms, Thartharella, calcisphaeras, } \\
\text { foraminifers, ostracods and molluscs. }\end{array}$ & $\begin{array}{l}\text { Reef mound and talus facies in medium to shallow } \\
\text { carbonate platform. Near to shore. Shallow, highly } \\
\text { to moderate agitated water. Between wave base } \\
\text { and storm base. Well-oxygenated, normal marine. }\end{array}$ & \multirow{2}{*}{ Multithecopora sp. E } & $\begin{array}{l}\text { late Bashkirian } \\
\text { (Tashatinian) }\end{array}$ \\
\hline Piedrasluengas & $\begin{array}{l}\text { Boundstone (Framestone- } \\
\text { Bafflestone) of chaetetids and corals }\end{array}$ & Base of massive limestones & $\begin{array}{l}\text { Peloids, micropeloids, oncoids, rugosans, chaetetids, } \\
\text { Thartharella, Tubiphytes, beresellids, spicules, } \\
\text { clacisphaeras, aoujgalids, foraminifers. }\end{array}$ & $\begin{array}{c}\text { Biostrome development above oolitic grainstone, in } \\
\text { shallow carbonate platform. Near to shore. Shallow } \\
\text { water, highly to moderate agitated water. Between } \\
\text { wave base and storm base. Well-oxygenated, } \\
\text { normal marine. }\end{array}$ & & $\begin{array}{l}\text { early Moscovian } \\
\text { (Vereian) }\end{array}$ \\
\hline Ribadesella & Bioclastic wackestone-packstone & $\begin{array}{l}\text { Silty limestones and marls } \\
\text { predominantly }\end{array}$ & $\begin{array}{l}\text { Peloids, micropeloids in cavities, little bioclasts in } \\
\text { matrix. Rugose corals, chaetetids, aoujgalids, } \\
\text { crinoids, ostracods, calcisphaera and foraminifers. }\end{array}$ & $\begin{array}{l}\text { Middle-shallow carbonate platform. Near to shore. } \\
\text { Shallow, highly to moderate agitate water. } \\
\text { Between wave base and storm base. Well } \\
\text { oxygenated, normal marine water. }\end{array}$ & $\begin{array}{l}\text { Aulopora sp. A \& Aulopora } \\
\text { sp. B }\end{array}$ & $\begin{array}{l}\text { early Moscovian } \\
\text { (Vereian) }\end{array}$ \\
\hline Este de Camasobres & $\begin{array}{l}\text { Bioclastic wackestone- } \\
\text { packstone/Boundstone (bafflestone) } \\
\text { of corals (Thrombolitic texture) }\end{array}$ & Silty limestone to marly limestone & $\begin{array}{l}\text { Peloids, micropeloids and automicrite in trombolitic } \\
\text { textures, big intraclasts (microbial), oncoids. } \\
\text { Rugosans, calcareous algae (Petschoria, } \\
\text { Anthracoporella), Tharthaerella, gastropoda, } \\
\text { ostracods, bryozoa and foraminifers. }\end{array}$ & $\begin{array}{l}\text { Shallow carbonate platform, with terrigenous influx. } \\
\text { Near to shore. Shallow water to moderately deep } \\
\text { subtidal conditions, highly to moderate agitate } \\
\text { energy. Between wave base and storm base. Well- } \\
\text { oxygenate, normal marine. }\end{array}$ & Multithecopora sp. F & $\begin{array}{l}\text { middle Moscovian } \\
\text { (Kashirian-early } \\
\text { Podolskian) }\end{array}$ \\
\hline Pico Guillermo & $\begin{array}{l}\text { Boundstone (bafflestone) of } \\
\text { Multithecopora with trombolitic } \\
\text { texture / micropeloidal wackestone- } \\
\text { packstone }\end{array}$ & Massive and bedded limestones & $\begin{array}{l}\text { Micropeloids, pseudostromatactic cavities and } \\
\text { intraclasts. Chaetetids, rugosans, crinoids, phylloid } \\
\text { algae, foraminifers and Thartharella. }\end{array}$ & $\begin{array}{l}\text { Reef-mound (biostromal facies) and associated } \\
\text { facies. Near to shore. Shallow, highly to moderate } \\
\text { agitated water. Between wave base and storm } \\
\text { base. Well-oxygenated, normal marine. }\end{array}$ & Multithecopora hontoriense & $\begin{array}{l}\text { middle Moscovian } \\
\text { (Kashirian-early } \\
\text { Podolskian) }\end{array}$ \\
\hline Prioro & $\begin{array}{l}\text { Boundstone of auloporids and } \\
\text { chaetetids/Trombolitic micrites } \\
\text { (cryptalgal texture) with boundstone } \\
\text { of auloporids corals }\end{array}$ & $\begin{array}{l}\text { Massive-limestones in the north } \\
\text { flank of the syncline and bedded } \\
\text { limestones in the south flank }\end{array}$ & $\begin{array}{l}\text { Peloids, intraclasts, micropeloids, breccias, rugosans, } \\
\text { chaetetids, Thartharella, echinoderms, gasteropods, } \\
\text { spicules, calcareous algae and foraminifers }\end{array}$ & $\begin{array}{l}\text { Mud-mounds and Reef-mounds. Near to shore. } \\
\text { Shallow, highly to moderate agitated water. } \\
\text { Between wave base and storm base. Well- } \\
\text { oxygenated, normal marine. }\end{array}$ & $\begin{array}{l}\text { Multithecopora sp. G \& } \\
\text { Neomultithecopora } \\
\text { cantabrica }\end{array}$ & $\begin{array}{l}\text { late Moscovian } \\
\text { (Podolskian) }\end{array}$ \\
\hline Playa de la Huelga & $\begin{array}{l}\text { Boundstones (bafflestone) of } \\
\text { Multythecopora with a packstone } \\
\text { matrix / Boundstone (Framestone) of } \\
\text { Neomultithecopora / Boundstone } \\
\text { (framestone) of chaetetids/ Bioclastic } \\
\text { packestone }\end{array}$ & $\begin{array}{l}\text { Massive and bedded limestones, } \\
\text { marls, calcareous sandstones and } \\
\text { breccias }\end{array}$ & $\begin{array}{l}\text { Small bioclastic remains, breccias, rugosans, } \\
\text { chaetetids, brachiopods, bryozoa, crinoids, mollucs } \\
\text { and foraminifers. }\end{array}$ & $\begin{array}{l}\text { Reef-mound and associated facies. Near to shore. } \\
\text { Shallow, highly to moderate agitated water. } \\
\text { Between wave base and storm base. Well- } \\
\text { oxygenated, normal marine. }\end{array}$ & $\begin{array}{l}\text { Multithecopora hontoriense, } \\
\text { Neomultithecopora } \\
\text { cantabrica \& Mastopora? } \\
\text { sp. }\end{array}$ & $\begin{array}{l}\text { late Moscovian } \\
\text { (Podolskian- } \\
\text { Myachkovian) }\end{array}$ \\
\hline $\begin{array}{l}\text { Celada de Roblecedo } \\
\text { Sur }\end{array}$ & $\begin{array}{l}\text { Boundstone of beresellids / } \\
\text { Boundstone of Sinopora }\end{array}$ & $\begin{array}{l}\text { Thin tabular beds of limestones } \\
\text { and some massive limestones }\end{array}$ & $\begin{array}{l}\text { Micropeloids, rims and cavities, pseudostromatactis } \\
\text { cavities. Thartharella, Anthracoporella, Tubiphytes, } \\
\text { chaetetids, foraminifers (textularids and fusulinids), } \\
\text { echinoderms, crinoids, calcisphaera, gastropods, } \\
\text { aoujgalids, brachiopods. }\end{array}$ & $\begin{array}{l}\text { Bioherm facies. Near to shore. Shallow, highly to } \\
\text { moderate agitated water. Between wave base and } \\
\text { storm base. Well-oxygenated, normal marine. }\end{array}$ & Sinopora sp. & $\begin{array}{l}\text { late Moscovian } \\
\text { (Myachkovian) }\end{array}$ \\
\hline
\end{tabular}

Table 2.- Localities and microfacies associated with the auloporid corals, geometry and lithology, main components, depositional environment and characteristics, morphotypes and age. 

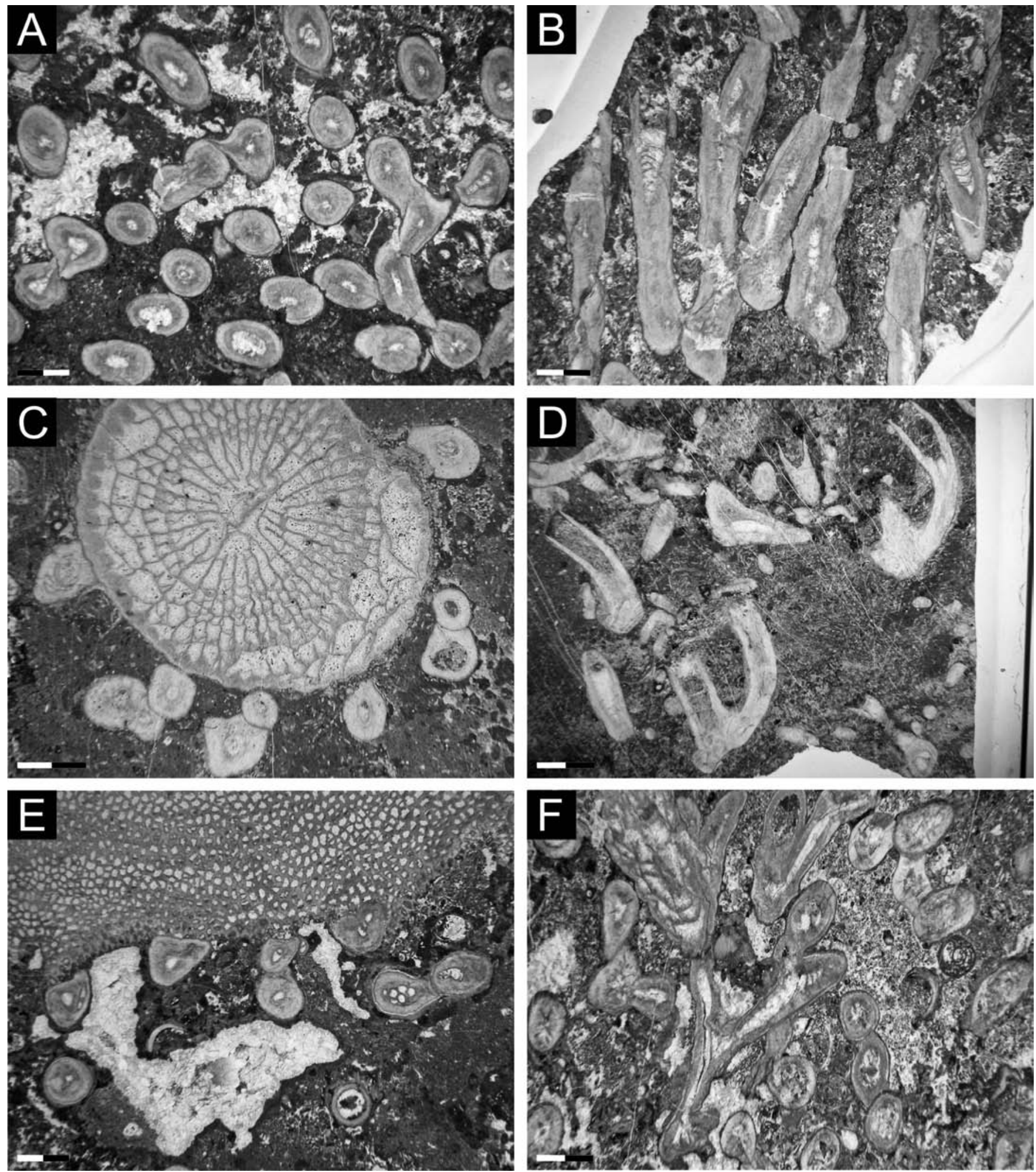

Fig. 10.- A-B) Multithecopora sp. D from Valdeteja-Las Majadas sections. Note the vertical and parallel development of the colony in a typical microbial matrix with pseudostromatactoid cavities, peloids and micritic envelope. C-F) Multithecopora sp. E. C-D) Samples from Las Ilces section. Note the encrusting habit on a rugosan from $\mathrm{C}$ in a microbial facies. D) Strategy of developing a stepped offsetting in response to an aggrading substrate in a Donezella core mound. E-F) Samples from Piedrasluengas section. E) Note the encrusting habit on a chaetetid in a microbial texture from the bioherm facies. F) Detail of the phaceloid to bushy habit of the colony. Scale bar is $2 \mathrm{~mm}$. 
ship (diameter/lumen) is low, because the lumen is usually open (Fig. 9E-F). This morphotype shows scarce, small septal spines, and acute shape and thick concave tabulae. These morphologic criteria suggest that this morphotype belongs to Mastopora. The genus Mastopora has been found previously only in the Silurian and Devonian, but as the section Playa de la Huelga has been dated as upper Moscovian (Podolskian) we use this genus with question mark.

\subsection{Microfacies and palaeoecological characteristics}

The sections sampled offer a large variety of environments, microfacies, and associations where the Carboniferous auloporids from the Iberian Peninsula could grow. Table 2 shows a compendium of data of the different microfacies found in studied samples (section, microfacies, geometry and lithology of the beds, components, depositional environment and characteristics derived from the study of the other components, fabrics, morphotypes, and age).

These data show that the dominant microfacies are coral or chaetetid boundstone (sensu Dunham, 1962). The bioclastic microfacies (e.g. bioclastic wackestone, packstone or grainstone) are common too, and they formed in a large variety of environments (flanks of buildups, shallow tidal flats or storm beds in inner or medial carbonate platforms).

The predominant host rock in these sections is massive limestone, occasionally with domical shape. Marls and silty limestones are subordinate in some sections. The most common occurrence of auloporoids is in the core of reef mounds, patch-reef and reef systems. Auloporids also occur in the capping beds of microbial mounds. The bedded limestones instead, are associated with bioclastic microfacies dependent on energetic environments, such as talus facies or storm beds.

The fossil assemblages related to the Auloporida in the Iberian Peninsula are dominated by the presence of crinoids, calcareous algae, chaetetids and other corals. It suggests that those communities are developed in shallow to moderately deep seas that present well-oxygenated and marine normal salinities.

\section{Results and Discussion}

The Carboniferous Auloporida from the Iberian Peninsula occurs in a large variety of environments and they were related to a wide spectrum of other invertebrate groups (Table 2).

The oldest occurrences are recorded in the upper Viséan (Middle Mississippian) in the Los Santos de Maimona and Cerro Almeña sections. Auloporids occur there in two different environments: reef flat and shallow-water platform. The Auloporids related to reef-flat platforms (Rodríguez et al., 1992; Rodríguez, 1996) show a diverse assemblage dominated by gigantoproductid brachiopods that are the base for the attachment of rugose corals and auloporids (Syringoporidae are the dominant auloporids). Well-preserved build-up beds alternate with storm beds where corals and brachiopods are reworked. Auloporids occur in growth position at the top of some beds developed in a shallow-water platform (above the wave-base) from Cerro Almeña. Fragments of the same corals occur in the middle part of the beds.

Auloporoids occur in more diverse environments, with Multithecoporidae the dominant auloporids in the Viséan from the Guadiato Basin. They lived at the top of microbial mounds (Sierra de la Estrella Section, Rodríguez-Martinez et al., 2003), in patch reefs (Antolín Section, Rodríguez and Rodríguez-Curt, 2002), and in shallow-water platforms affected by storms (El Collado Section; Fuenteobejuna Section, Cózar et al., 2007; and Adelfilla Section). In all cases they are associated with diverse assemblages that include rugose corals, chaetetids, brachiopods, crinoids, bryozoans, algae, cyanobacteria and foraminifers.

The Serpukhovian rocks from the Guadiato Basin yielded a poor assemblage of auloporoids (San Antonio and La Cornuda sections, Gómez-Herguedas and Rodríguez, 2008) that lived in small mud mounds mainly composed of algae, rugose corals, chaetetids and peloidal wackestone produced by microbial communities.

During the Pennsylvanian there is a change in the benthic communities, but the Multithecoporidae were still present and became dominant components in many environments. Consequently, they occur in many Pennsylvanian localities from the Cantabrian Zone.

Auloporids occur in the Bashkirian and Moscovian, being a main or a secondary component of reef mounds built by them, associated with calcareous algae (Donezella, Anthracoporella and/or phylloid algae), as well as rugose corals, chaetetids and microbial communities (Las Ilces Section, Coronado and Rodríguez, 2009; Prioro section, van Loon, 1971; Celada de Roblecedo and Pico Guillermo sections (van der Graaff, 1971b). As in the Mississippian, they also occur at the top of microbial and algal mounds and in surrounding facies (Valdeteja Section, Eichmüller, 1985). Auloporoids are also common in shallow-water platforms. They built biostromes associated with rugose corals and chaetetids (Piedras Luengas Section, Minwegen, 2001) and built reefal structures associated also with rugose corals and chaetetids (Playa de la Huelga Section, Minwegen 2001; Bahamonde, 2008). Occasionally, they occur in shallow-water platforms with soft bottom, growing on rugose corals or brachiopods (Playa de la Huelga, Rodríguez and Ramírez, 1987; Ribadesella, Rodríguez et al., 1997 and Este de Camasobres sections).

Most of the Auloporida that are found in these environments belong to the superfamily Syringoporicae, which show phaceloid and more rarely cerioid morphology, with a diverse density of occurrence and growth-directions of corallites. The growth strategies of tabulate corals were analyzed by Scrutton (1997). They depend on the strength of substrate, the competitiveness with other organisms and the environmental conditions during the colony development. The Syringoporicae of the Iberian Peninsula show diverse strategies: 

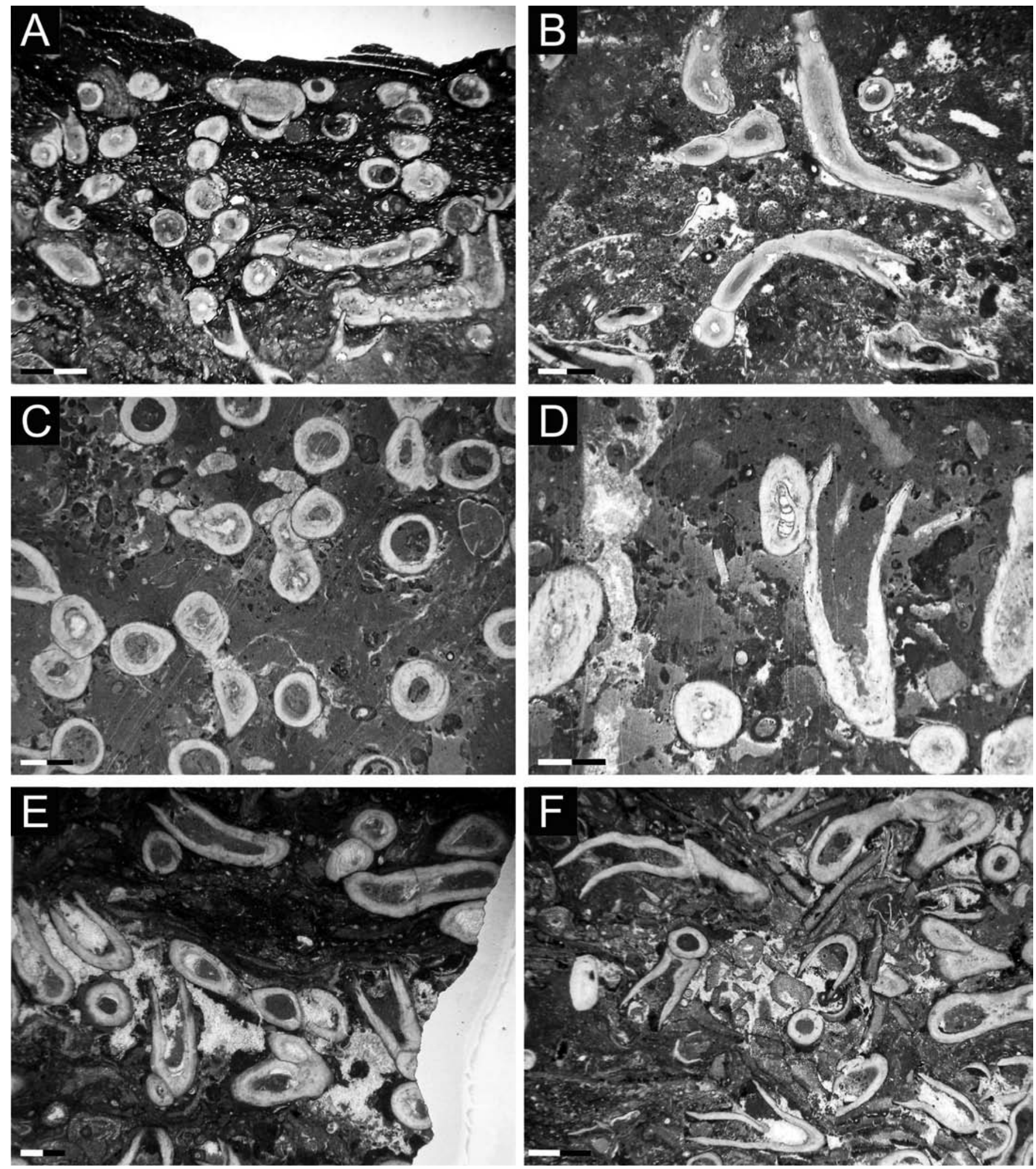

Fig. 11.- A-B) Multithecopora sp. F from Este de Camasobres section. A) Detail of the reworked facies where the corallites show fragmentation and abrasion. B) Reptant growth of the corallites in microbial matrix. C-D) Multithecopora sp. G from Prioro section. Growth of the colonies in a microbial substrate and presence of open calices with thicker walls. E-F) Sinopora sp. from Celada de Roblecedo section. E) Prostrate and tumbled corallites growing in steps. F) Reworked facies of Sinopora with abundant phylloid algae. Scale bar is $2 \mathrm{~mm}$. 

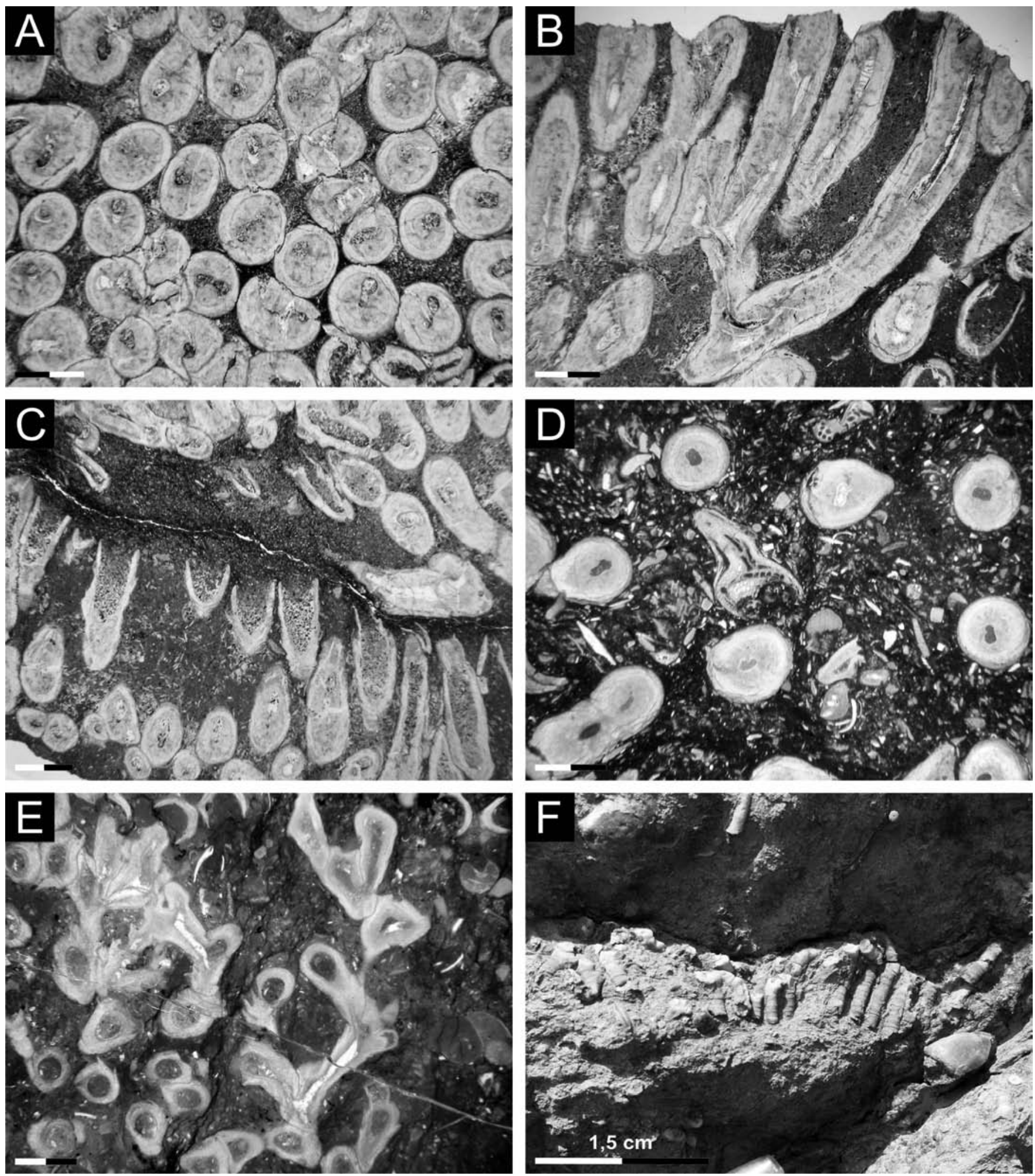

Fig. 12.- Multithecopora hontoriense Rodríguez and Ramírez, 1987. A-C) Samples from Pico Guillermo section. Note the phaceloid habit and dense packing of corallites producing a massive colony. C) Stepped offsetting developed in response to an aggrading substrate with vertical corallites in the top and tumbled or prostrate ones in the bottom of the colony. D-F) Samples from Playa de la Huelga section. Note the vertical and parallel development of the colony in D and F. E shows a branched development with a short growth of the corallites. Scale bar is $2 \mathrm{~mm}$. 

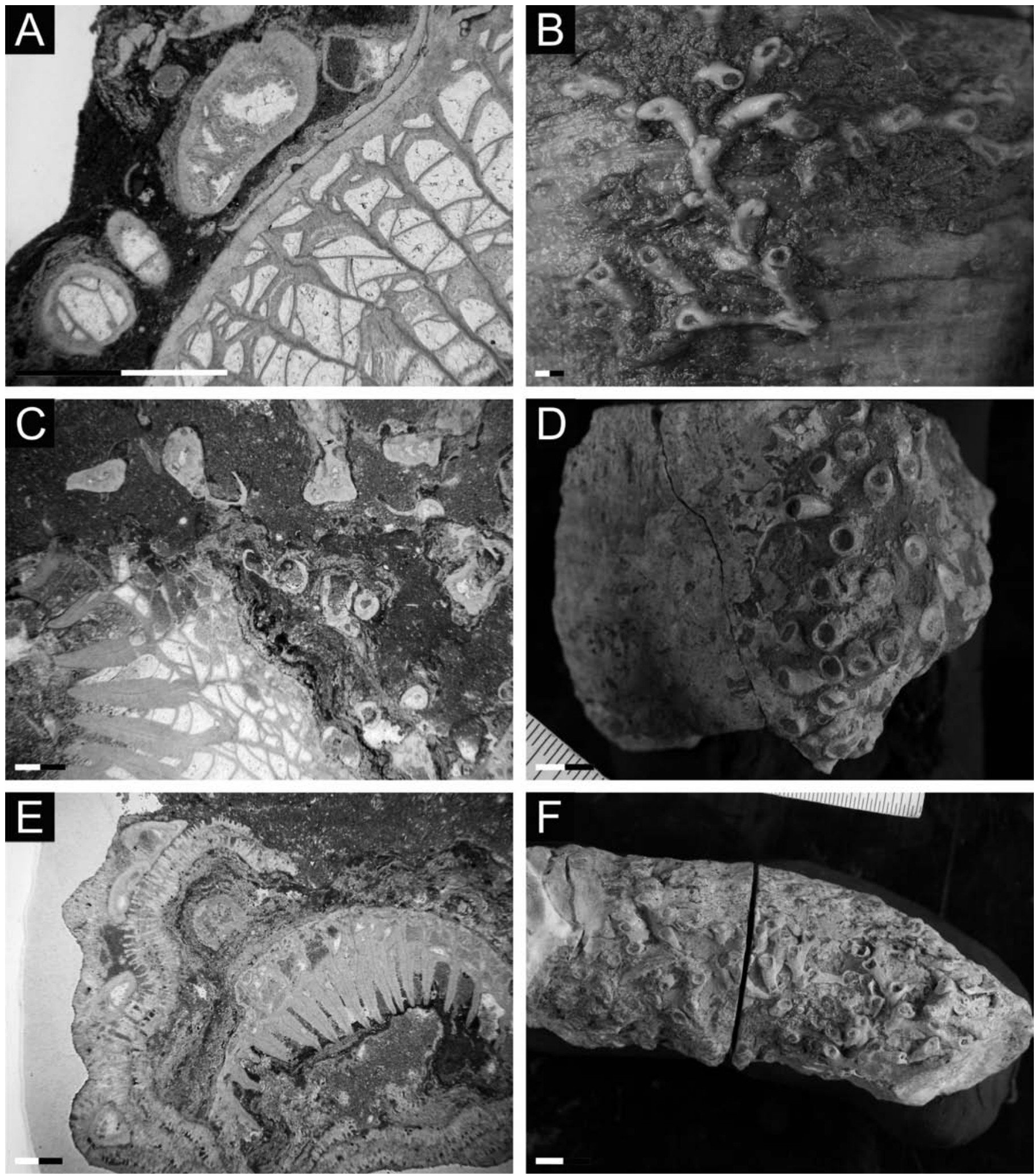

Fig. 13.- A-B) Aulopora sp. A from Ribadesella section. A) Detail in thin section of this morphotype. Note the thin infundibuliform tabulae and the incrustation on a rugose coral. B) Note the reptant habit of the corallites growing on a rugosan. C-F) Aulopora sp. B from Ribadesella section. C) Detail of the branching bushy habit of a colony. D) Detail in thin section from the corallites; note the differences with Aulopora sp. A. E) Encrustation of a chaetetid on a rugosan and Aulopora on and between the chaetetid. F) Reptant growth on a rugose coral. Scale bar is $2 \mathrm{~mm}$. 


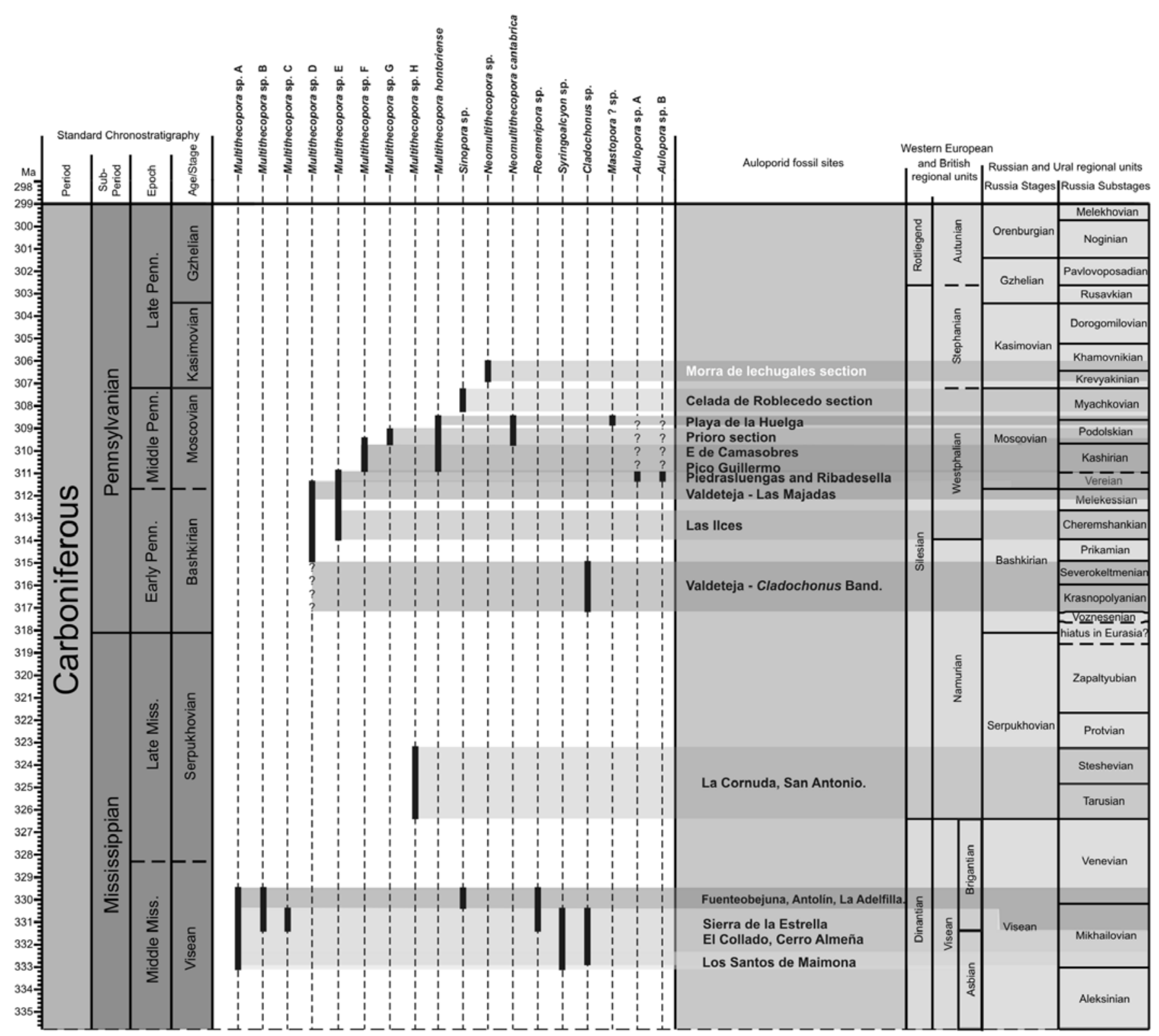

Fig. 14.- Biostratigraphical distribution of the auloporid corals found in the Iberian Peninsula. Note the gap between the upper part of the Mississippian and the lower part of the Pennsylvanian.

Syringopora and Syringoalcyon in Los Santos de Maimona and Cerro Almeña Sections show phaceloid (palisade) colonies with the main development in the periphery (Fig. 7 E-I). This strategy is possible because of the presence of hard substrate such as brachiopod shells or rugose corals and protection against high energy of the waves. The vertical growth is unlimited in Cerro Almeña, but limited by the level of low tides in Los Santos de Maimona.

Multithecopora hontoriense from Playa de la Huelga and Pico Guillermo sections shows a similar strategy (Fig. 12. A-B, F). In this case, the corallites are closely packed and show connecting tubuli. These colonies grew on chaetetid colonies. Roemeripora from Fuenteobejuna Section (Fig. 8. E-F) and Neomultithecopora cantabrica from Playa de la Huelga section share the same strategy and develop massive colonies (Fig. 8. C-D).
Syringopora sp. B, Multithecopora sp. A and Multithecopora sp. B from Antolín and Sierra de la Estrella sections show a lower density of corallites and branched colonies (Fig. 5. B-C). It is probably due to the substrate. It is composed of peloidal carbonate produced by microbial communities. Due to early lithification, the substrate was firm but not hard, providing less support for the high density of corallites. This strategy is also used by Multithecopora hontoriense (Fig. 12. E), Multithecopora sp. C, Multithecopora sp. H (Playa de la Huelga, Pico Guillermo, El Collado, La Cornuda sections, respectively) and Neomultithecopora sp. from Morra de Lechugales section (Merino-Tomé et al. 2009). All these morphotypes show bushy colonies with unlimited vertical growth. In the case of $M$. hontoriense and Neomultithecopora cantabrica, they grew on chaetetid skeletons and brachiopod shells (Fig, 7. C). 
Multithecopora sp. D (Valdeteja section), Multithecopora sp. B (Fuenteobejuna section), Multithecopora sp. F (Este de Camasobres section), Neomultithecopora cantabrica (Prioro and Playa de la Huelga sections) and some specimens of Multithecopora sp. A (Sierra de la Estrella) show an initial stage of reptant growth (Fig. 5. E-F; 7. B; Fig. 11. B) followed by an erect growth with corallites vertical and parallel forming typical phaceloid colonies (Fig. 10A-B).

Multithecopora sp. E (Las Ilces and Piedrasluengas sections), Sinopora (Celada de Roblecedo Section), Multithecopora sp. G (Prioro Section), some colonies of Multithecopora sp. F (Este de Camasobres Section) and Sinopora (Celada de Roblecedo Section) follow the strategy of developing a stepped offsetting in response to an aggrading substrate (when they grew related to microbial communities) or to competition with other organisms. Well-preserved examples of this strategy are found also in Multithecopora hontoriense (Pico Guillermo section) and Multithecopora sp. E (Las Ilces section), where the colonies are influenced by the substrate that cut the vertical development and finally is distorted in several bands (Fig. 10. D; Fig. 12. C).

The Auloporicae that do not occur in buildups and show also diverse growth strategies, adapted usually to environments with high energy or high terrigenous influx:

Mastopora? occurs in calcareous sandstones with planar lamination associated with encrusting bryozoans and crinoidal ossicles. It grew in an environment of quite high energy and near shore. It shows reptant growth developing a complete encrusting sheet (Fig. 9F).

Aulopora morphotypes occur mainly in marly facies, associated with rugose corals (Fig. 13A-F) and chaetetids. They grew in columnar profiles (Aulopora sp. A) or in branching bushes (Aulopora sp. B). All occurrences whatever autochthonous or allochthonous, show evidence of terrigenous influx.

Cladochonus morphotypes show simple lateral branches with a reptant growth habit and zig-zag trajectories (Fig.8B). Scrutton (1997) regarded this strategy as due to development in a soft substrate.

As explained above, the auloporids from the Iberian Peninsula occur in different habitats, developed diverse strategies and were related to different fossil assemblages. However, there is a typical assemblage, which is repeated in many cases. It is the "Chaetetid-auloporoid-rugose coral buildups" described by West (1988), Minwegen (2001) and Wahlman (2002), as an interrelationship between corals and chaetetids, using each other as substrate and framework. The Pennsylvanian buildups from the Iberian Peninsula show different assemblages of reef-building organisms, including Donezella, Anthracoporella, Petschoria, phylloid algae and bryozoans. Auloporoids are present in all of them, but their most common association includes the presence of chaetetids.

Figure 14 shows the stratigraphical distribution of the morphotypes and species of auloporoid corals studied herein. The auloporoids show many overlaps between the ranges of the morphotypes in both regions (Ossa-Morena and Cantabrian zones). There is also a reduced representation in the uppermost Mississippian and lowermost Pennsylvanian. In contrast, the record is quite complete in the Viséan and from the Bashkirian to Moscovian. It is due to the scarcity of outcrops and/or the unfavourable environments. As the identification and assignation of new species names is still not completely finished, this is a provisional chart, which will be improved with further studies.

\section{Conclusions}

Auloporid corals are highly diverse in the Carboniferous of the Iberian Peninsula, mainly in the outcrops of the Ossa-Morena Zone (Mississippian age) and Cantabrian Zone (Pennsylvanian age). The auloporids have been identified following the criteria proposed by Tchudinova in (1980) with some modifications. They have been subdivided into morphotypes and grouped according to common characteristics.

Eighteen morphotypes and two species belonging to nine nominal genera have been identified (Multithecopora sp. A-H, Syringopora sp. A-B, Aulopora sp. A-B, Cladochonus sp. A-B, Syringoalcyon sp., Roemeripora sp., Sinopora sp., Mastopora? sp., Multithecopora hontoriense and Neomultithecopora cantabrica).

Syringopora, in the Carboniferous from the Iberian Peninsula is only present in the Mississippian. The dominant genus through the Carboniferous is Multithecopora, represented by 8 morphotypes and one species. Forms with pseudocerioid growth habit were derived from phaceloid forms: Roemeripora from Syringopora in the Mississippian and Neomultithecopora from Multithecopora in the Pennsylvanian.

The genus Syringoalcyon, which is globally very scarce, is quite abundant in the Los Santos de Maimona Basin. The validity of this genus is doubtful and it will be further studied in the future.

These corals inhabited different environments, and show diverse growth strategies. They lived in buildups (reefmounds, patch-reefs), on microbial mounds, in reef-flats and carbonate shallow platforms). The microfacies study shows that these corals inhabited shallow, well oxygenated waters with normal marine salinity. Those environments allowed the development of diverse communities in which the auloporoids were related to rugose corals, chaetetids, crinoids, brachiopods, algae, foraminifers, molluscs, etc. The biostratigraphic distribution has been established for the proposed morphotypes as a provisional chart, which will be improved with further taxonomic studies.

\section{Acknowledgements}

Ian D. Somerville and Esperanza M. Fernández-Martínez who critically reviewed an early draft, have contributed significantly to the improvement of the final version. This 
study has been supported through the Spanish Science Ministry (Project CGL 2009-1034/BTE) and the UCM Research Group 910231. Ismael Coronado acknowledges financial support through an UCM FPI grant. The authors are grateful to Isabel Díaz Megías for her help in the preparation of thin sections. This article is a contribution to the Spanish Working Group IGCP 56.

\section{References}

Alonso, J.L. (1989): Síntesis cartografica de la Region del Manto del Esla. Trabajos de Geología 18, 155-163.

Aretz, M., Herbig, H.-G. (2010): Corals from the Upper Viséan of the southern Azrou-Khenifra Basin (Carboniferous, Central Moroccan Meseta). Palaeoworld 19, 294-305. doi:10.1016/j.palwor.2010.08.003

Bahamonde, J. R., Kenter, J. A. M., Della Porta, G., Hoeflaken, F. V. (2008): Facies belt of a Carboniferous carbonate platform (San Antolín- La Huelga section, NE Cantabrian Zone, Nothern Spain). Trabajos de Geología 28, 69-86.

Boll, F.-C. (1985): Rugose Korallen der Flachwasser-Fazies im Oberkarbon des kantabrischen Gebirges (Nordspanien). Palaeontographica: Paläozoologie-Stratigraphie 190, 90 p.

Colmenero, J. R., Fernandez, L. P., Moreno, C., Bahamonde, J. R., Barba, P., Heredia, N., Gonzalez, F. (2002): Carboniferous. In: W. Gibbons and T. Moreno (Eds.), The geology of Spain: Geological Society, Bath, United Kingdom: 93-116.

Coronado, I. (2008): Estudio biosedimentario de la sección de Las Ilces, Formación Cosgaya, Carbonífero, Master Project, Complutense University, Madrid: 79 p.

Coronado, I., Rodríguez, S. (2009): Análisis de microfacies de los montículos de la Formación Cosgaya. Sección de Las Ilces, Pensilvánico, Cantabria. Coloquios de Paleontologia 59, 61-91.

Corrochano, D., Barba, P., Colmenero, J. (in press) Transgressiveregressive sequence stratigraphy of Pennsylvanian Donezella bioherms in a foreland basin (Lena Group, Cantabrian Zone, NW Spain). Facies, 1-20. doi: 10.1007/s10347-011-0282-0

Corrochano, D., Barba, P., Colmenero, J. R., Alonso Chaves, F. M., Fernandez Rodriguez, C., Morales Gonzalez, J. A., Colombo Pinol, F. (2009): Distribucion de facies y evolucion de un margen de plataforma carbonatada pensilvaniense en el sector lois-ciguera de la cuenca carbonifera central asturiana (zona cantabrica). Geogaceta 46, 63-66.

Cózar, P (2004): Foraminiferal and algal evidence for the recognition of the Asbian/Brigantian boundary in the guadiato area (Mississippian, southwestern Spain). Revista Española de Micropaleontología 36 (3), 367-388.

Cózar, P., Rodriguez, S. (1999): Descripcion e interpretacion de los afloramientos del carbonifero inferior en las proximidades de Penarroya-Pueblonuevo (Cordoba, Espana). Coloquios de Paleontologia 50, 161-200.

Cózar, P., Rodríguez, S. (2000): Caracterización estratigráfica y sedimentológica del Viseense superior de Sierra Boyera (Area del Guadiato, SO de España). Revista de la Sociedad Geológica de España 13, 91-104.

Cózar, P., Rodríguez, S. (2001): Precisiones sedimentológicas y bioestratigráficas en la Unidad del Fresnedoso, Área del Guadiato (Mississippiense, SO de España). Boletín de la Real Sociedad de Historia Natural (Sección Geológica) 96, 69-84.

Cózar, P., Rodríguez, S. (2004): Pendleian (early Serpukhovian) marine carbonates from SW Spain: sedimentology, biostratigraphy and depositional model. Geological Journal 39, 25-47. doi: 10.1002/ gj. 942
Cózar, P., Rodríguez-Martínez, M., Falces, S., Mas, R., Rodríguez, S. (2003): Stratigraphic setting in the development of microbial mud mounds of the Lower Carboniferous of the Guadiato Area (SW Spain). SEPM Special Publication 78, 57-67.

Cózar, P., Somerville, I. D., Rodríguez, S., Medina-Varea, P. (2007): New genera of late Viséan metaspondyl dasycladales from the Fuenteobejuna section (Mississippian of the Guadiato Valley, southwestern Spain). Neues Jahrbuch für Geologie und Paläontologie - Abhandlungen 246, 97-109. doi: 10.1127/0077-7749/2007/0246-0097

Dunham, R. J. (1962): Classification of carbonate rocks according to depositional texture. Memoir - American Association of Petroleum Geologists, 108-121.

Eichmüller, K. (1985): Die Valdeteja Formation: Aufbau und Geschichte einer oberkarbonischen Karbonatplattform (Kantabrisches Gebirge, Nordspanien). Facies 13, 45-153.

Fernández, L. P., Barba, P., (1992): Zonacion ambiental de mounds algales del Carbonifero de la Zona Cantabrica (NO de Espana. Geogaceta 12, 95-96.

Fernández, L. P., Fernández-Martínez, E., Méndez-Bedia, S., Rodríguez, S., Soto, F. (1995): Devonian and Carboniferous Reefal Facies from the Cantabrian Zone (NW Spain). In: A. Perejón (Eds.), VII International Symposium on Fossil Cnidaria and Porifera: Field trip A, Madrid: p. 76.

Gómez-Herguedas, A., Rodríguez, S. (2008): Palaeoenvironmental analysis based on rugose corals and microfacies: a case study at $\mathrm{La}$ Cornuda section (early Serpukhovian, Guadiato Area, SW Spain). Lethaia 42, 39-54. doi: 10.1111/j.1502-3931.2008.00106.x

van der Graaff, W. J. E (1971a): The Piedrasluengas Limestone, a possible model of limestone facies distribution in the Carboniferous of the Cantabrian Mountains. Trabajos de Geologia 3, 151-159.

van de Graaff, W. J. E. (1971b): Three Upper Carboniferous, limestone-rich, high-destructive delta systems with submarine fan deposits, Cantabrian Mountains, Spain. Leidse Geologische Mededelingen 46, 157-235.

Herbig, H.-G. (1984): Rekonstruktion eines nicht mehr existenten Sedimentations-raums; Die Kalkgeroelle im Karbon-Flysch der Malagiden (Betische Kordillere, Suedspanien). Facies 11, 1-108. doi: 10.1007/BF02536907

Hill, D. (1981): Rugosa and Tabulata. Teichert C (ed) Treatise on Invertebrate Paleontology, Part F [Coelenterata] Suppl 1. Colorado and Lawrence, Kansas: 672 p.

Julivert, M. (1971): Decollement tectonics in the Hercynian Cordillera of Northwest Spain. American Journal of Science 270, 1-29.

van Loon, A. J. (1971): The stratigraphy of the Westphalian C around Prioro (Prov. Leon, Spain). Trabajos de Geologia 3, 231-263.Lotze, F. (1945): Zur Gliederung der Varisziden der Iberischen Meseta. Geotektonische Forschungen 6, 78-92.

Mamet, B. (1974): Une zonation par foraminifères du Carbonifére inférieur de la Téthys Occidentale. VII Congrès International de Stratigraphie et de Géologie du Carbonifère, Comptes Rendus 3 391-408.

Martínez Chacon, M. L., Merino-Tome, O. A., Villa, E. (2001): Brachiopod and fusulinid assemblages of Kasimovian (Pennsylvanian) age from the Andara Massif (Picos de Europa, northern Spain). Scripta Geologica Special Issues 7, 54-91.

Merino-Tomé, O., Bahamonde, J. R., Samankassou, E., Villa, E. (2009): The influence of terrestrial run off on marine biotic communities: An example from a thrust-top carbonate ramp (Upper Pennsylvanian foreland basin, Picos de Europa, NW Spain). $\mathrm{Pa}$ laeogeography, Palaeoclimatology, Palaeoecology 278, 1-23. doi: 10.1016/j.palaeo.2009.04.002

Minwegen, E. (2001): Die Biokonstruktionen im Pennsylvanium des Kantabrischen Gebirges (Nordspanien). [Pennsylvanian bioconstructions of the Cantabrian Mountains (Northern Spain).] Koelner 
Forum fuer Geologie und Palaeontologie 9, 139.

Nelson, S. J. (1977): Mississippian syringoporid corals, Southern Canadian Rocky Mountains. Bulletin of Canadian Petroleum Geology 25, 518-581.

Niko, S. (1998): Auloporid Tabulate Corals from the Carboniferous Ichinotani Formation, Gifu Prefecture Bulletin of the National Science Museum Series C, Geology and Paleontology 24, 113-128.

Nowinski, A. (1991): Late Carboniferous to Early Permian Tabulata from Spitsbergen. Palaeontologia Polonica 51, 3-74.

Pérez-Estaún, A., Bea, F., Bastida, F., Marcos, A., Matínez-Catalán, J. R., Martínez-Poryatos, D., Arenas, R., Díaz-García, F., Azor, A., Simancas, J. F., González-Lodeiro, F. (2004): La cordillera varisca europea: El Macizo Ibérico. In: J.A. Vera (ed.), Geología de España. Instituto Geológico y Minero de España and Sociedad Geológica de España, Madrid: pp. 19-230.

Poty, E. (2010): Morphological limits to diversification of the rugose and tabulate corals. Palaeoworld 19, 389-400. doi:10.1016/j.palwor.2010.09.006

Rodríguez-Martinez, M., Cózar, P., Mas, R., Rodriguez, S. (2003): Upper Viséan Saccamminopsis-sponge microbial mud mounds, Sierra de la Estrella, southwestern Spain. In: W. M. Ahr, P. M. Harris, W. A. Morgan and I. D. Somerville (Eds.), Permo-Carboniferous Carbonate Platforms and Reefs - Special Publication - Society for Economic Paleontologists and Mineralogists Memoir 78, 189-200.

Rodríguez, S. (1984): Corales rugosos del Carbonifero del este de Asturias. Carboniferous rugose corals of eastern Asturias. Universidad Complutense de Madrid, Madrid, Spain: 592 p.

Rodríguez, S. (1985): Aportaciones de los corales rugosos a la datacion del Devonico y Carbonífero de Ossa-Morena. Temas Geológicos y Mineros. Instituto Geológico y Minero de España 7, 1-6.

Rodríguez, S. (1996): Development of coral reef-facies during the Viséan at Los Santos de Maimona, SW Spain. In: P. Strogen, I. D. Somerville and G. Ll. Jones, Recent Advances in Lower Carboniferous Geology, Geological Society Special Publications 107, 145152.

Rodríguez, S., Falces, S. (1996): Los corales rugosos del Carbonifero de Ossa-Morena; estado actual de los conocimientos. Revista Española de Paleontología Special number X Jornadas de Paleontología, 97-102.

Rodríguez, S., Falces, S., Arribas, M. E., de la Peña, J. A., Comas Rengifo, M. J., Moreno Eiris, E. (1992): Analisis paleontologico y sedimentologico de la cuenca carbonifera de Los Santos de Maimona (Badajoz); descripcion litoestratigrafica y aspectos sedimentologicos de las unidades. Coloquios de Paleontologia 44, 49-89.
Rodríguez, S., Falces, S., Cózar, P. (1997): Development of dissepimented rugose corals in Moscovian soft bottom environments at Ribadesella (Asturias, NW Spain). Boletín de la Real Sociedad deHistoria Natural (Geología) 92, 209-223.

Rodríguez, S., Ramírez, C. (1987): Los siringopóridos de la Seccion de la Playa de la Huelga (Carbonífero, Asturias, NW de España). Boletín de la Real Sociedad Española de Historia Natural (Geologia) 83, 57-82.

Rodríguez, S., Rodríguez-Curt, L. (2002): Reconstrucción de una plataforma carbonatada Viseense no preservada en el Área del Guadiato (Córdoba, SO de España). Geogaceta 32, 283-286.

Rodríguez, S., Rodríguez-Curt, L., Hernándo, J. M. (2001): Estudio de los aulophyllidae (rugosa) del viseense superior de la unidad de la Sierra del Castillo (Cordoba, Espana). Coloquios de Paleontologia $52,47-78$.

Rodríguez, S., Somerville, I. D. (2007): Comparisons of rugose corals from The Upper Viséan of SW Spain and Ireland: implications for improved resolutions in Late Mississippian coral biostratigraphy. Schriftenreihe der Erdwissenschaftlichen Kommissionen. 17, 275305

Said, I., Rodríguez, S., Berkhli, M., Cózar, P., Gómez-Herguedas, A. (2010): Environmental parameters of a coral assemblage from the Akerchi Formation (carboniferous), Adarouch area, central Morocco. Journal of Iberian Geology 36, 7-19.

Sando, W. J. (1984): Syringoporoid corals: guides to the stratigraphy of upper Paleozoic rocks in the Western Interior Region. U.S. Dept. of the Interior, Geological Survey.

Scrutton, C. T. (1997): Growth strategies and colonial form in tabulate corals. Boletín de la Real Sociedad Española de Historia Natural (Geologia) 91, 179-191.

Stasińska, A. (1982): Colony structure and systematic assignment of Cladochonus tenuicollis McCoy, 1847 (Hydroidea). Acta Palaeontologica Polonica 27, 59-64.

Tchudinova, I. I. (1975): Revision of the Syringopora described by A.A. Stuckenberg. Paleontological Journal 9, 7-19.

Tchudinova, I. I. (1980): Morphogenesis of Syringoporida. Acta Palaeontologica Polonica 25, 505-511.

Tourneur, F., Boulvain, F., Young, G. A. (1995): Reinterpretation of Syringoalcyon Termier and Termier 1945 (Tabulata); syringoporid coral with epibionts. VII Int. Symp. On Fossil Cnidaria and Porifera. Madrid: 92-93.

Villa, E. (1995): Fusulinaceos carboniferos del este de Asturias (N de España). Carboniferous Fusulinacea from eastern Asturias, northern Spain. Biostratigraphie du Paleozoique 13, 261.

Villa, E., Sánchez de Posada, L. C., Fernández, L. P., Martinez-Chacón, M. L., Stavros, C. (2001): Foraminifera and biostratigraphy of the 